Bogusław Śliwerski

Uniwersytet Łódzki

\title{
RECEPCJA I APLIKACJE PEDAGOGIKI ORAZ PSYCHOLOGII KRYTYCZNEJ
}

\section{The reception and applications of critical pedagogy and critical psychology}

Summary: The article presents research on the reception of critical pedagogy and critical psychology in the humanities and social sciences in Poland from the late 1980 os through the first half of the second decade of the 21st century. Metatheoretical and educational research was conducted in various Polish universities on basic pedagogical categories and educational processes in schools whose premises are rooted in the philosophy of the Frankfurt School, as well as French, Italian and Anglo-American critical sociology of education. The text presents the extent to which translations of classical treatises from critical schools of philosophy, pedagogy and psychology into Polish, as well as hermeneutical studies from these fields that have not been translated into Polish, on the one hand contributed to strengthening the political and social transformations that began in 1989 and, on the other hand, were, as part of comparative research, part of a completely new interpretation of concepts, language and critical theory within the Polish context.

Ke y w o r d s : critical philosophy, critical pedagogy, critical sociology, critical psychology, antipedagogy, resistance, emancipation, democracy, clinic training, sociopathology of education

Ponad ćwierć wieku temu, jeszcze w okresie PRL-owskiej cenzury, ukazał się mój pierwszy tekst o najbardziej radykalnym odłamie pedagogiki krytycznej, jakim jest antypedagogika ${ }^{1}$, by w kilka lat później wprowadzić do typologii współczesnych teorii i nurtów wychowania także nieobecną w Polsce recepcję rozpraw niemieckich filozofów oraz pedagogów negatywnych i krytycznych ${ }^{2}$. Uczestniczący w przełomowym dla polskiej pedagogiki seminarium Zbigniewa Kwiecińskiego i Lecha Witkowskiego „Nieobecne dyskursy” naukowcy z Poznania, Gdańska, Wrocławia, Torunia, Słupska, Bydgoszczy oraz Łodzi uprzystępnili w bardzo krótkim czasie różne nurty i podejścia badawcze pedagogiki krytycznej, nawiązującej do szkoły amerykańskiej, ale marginalnej w tym kraju, jak i do europejskiej pedagogiki krytycznej, znacznie szerzej, głębiej przenikającej do badań naukowych także w III RP. Nie wszyscy

\footnotetext{
${ }^{1}$ Bogusław Śliwerski, „Czy musimy wychowywać?”. Harcerz Rzeczypospolitej 5 (1988).

${ }^{2}$ Tegoż, Wspótczesne teorie i nurty wychowania (Kraków: Oficyna Wydawnicza „Impuls” 1998); tegoż, „Pedagogika negatywna”, w: Pedagogika. Podręcznik akademicki, red. Zbigniew Kwieciński, Bogusław Śliwerski, tom I (Warszawa: Wydawnictwo Naukowe PWN 2003).
} 
pedagodzy byli wówczas przekonani, że stan pęknięcia, radykalnego odcięcia się polskiej humanistyki od monistycznej, zdegenerowanej ideologicznie pedagogiki socjalistycznej musi stać się trwałym osiągnięciem czasów transformacji społecznopolitycznej, posttotalitarnej czy postkolonialnej. Niektórzy mieli jeszcze nadzieję, że mimo wszystko w naukach o wychowaniu nadal będzie obowiązywać paradygmat pozytywistyczny, instrumentalny, w służbie etatystycznej indoktrynacji czy urabiania społeczno-politycznego młodych pokoleń z wykorzystaniem struktur i procesów oświaty obowiązkowej.

Okres ostatniego dwudziestopięciolecia III RP potwierdza, że bardzo szybo odeszliśmy od idei, które stały się fundamentalnymi przesłankami rozkładu totalitarnego systemu społecznego w Polsce i Europie Wschodniej, rugując - także za sprawą pedagogiki - edukację obywatelską, wychowanie demokratyczne, odmawiając autonomii licznym podmiotom edukacji czy środowiskom wychowawczym, a nawet używając różnych form presji czy siły przeciw ruchom oporu społecznego. Znacznie powiększyło się grono kontynuatorów tego nurtu badawczego. Do recepcji Szkoły Frankfurckiej z biegiem lat włączane były badania i publikacje francuskiej i włoskiej - krytycznej filozofii i socjologii edukacji, a także pedagogiki krytycznej.

Polska pedagogika intensywnie, ale też i ewolucyjnie, wpisywała się rozwój pedagogiki krytycznej w minionym okresie, a mimo to nadal nie jest w stanie w tak krótkim okresie czasu nadrobić opóźnień i nieobecności niektórych z jej dyskursów, które od szeregu lat są rozwijane na naszym kontynencie. Polscy naukowcy z różnych ośrodków akademickich przybliżają dzięki własnym studiom i przekładom to, co jest najbardziej aktualne w stanie rozwoju tej myśli, ale też muszą powracać do źródeł, które nie były przecież w naukach o wychowaniu przedmiotem pogłębionej recepcji czy nowych reinterpretacji. Nadal nie ma przekładów na język polski klasyki pedagogiki krytycznej w Niemczech: Das Ende der Erziehung (1985) Hermana Giesecke, Performatiuve Pädagogik (1999) Martina Kocha, Abschied von der Aufklärung (1990) Heinza-Hermanna Krügera, Didaktiuk und Kommunikation (1973) Dietera Lenzena czy Erziehung und Emanzipation (1973) Klausa Mollenhauera.

Interesującym przykładem jest nurt, który rozwija się w Europie pod nazwą „pedagogika dekonstrukcyjna”, a w naszym kraju może się już pochwalić własnymi osiągnięciami. Debata na ten temat w pedagogice toczy się bowiem w perspektywie studiów poststukturalistycznych czy postmodernistycznych, mających już bogatą literaturę. Ten rodzaj myślenia odzwierciedla się w badaniach dotyczących takich kategorii postrukturalistycznych jak podmiot, tożsamość, rozum i racjonalność. Refleksję na temat tych fenomenów wodniesieniu tak do wychowania, jak i kształcenia, podjął zwłaszcza zespół pedagogów ogólnych, teoretyków wychowania i pedeutologów, ujawniając przy tej okazji iluzję autonomii nauczycieli, uczniów, rodziców, dyrektorów szkół, wychowawców, placówek oświatowych i innych.

Pojawiają się w tym nurcie interesujące recepcje rozpraw Jacquesa Lacana, badania analityczne władzy w świetle krytyki Michela Foucaulta czy postmodernistyczne nawiązania do rozpraw Jean-François Lyotarda, które były 
odnoszone do problematyki emancypacji w wychowaniu i kształceniu. Możemy także poszczycić się wielością rozpraw z zakresu dekonstrukcji wychowania czy kształcenia, których autorzy nawiązywali do początków myśli związanej z naturalizmem. Przykładem tego są znakomite studia i debaty Aleksandra Nalaskowskiego dotyczące relacji miedzy naturą a wychowaniem człowieka czy Zbyszka Melosika i Agnieszki Gromkowskiej-Melosik na temat ciała oraz cielesności w procesie socjalizacji młodych pokoleń. Punktem wyjścia dla tak osadzonej pedagogiki dekonstrukcyjnej jest natura jako cel wychowania, generująca pedagogiczne oraz moralne kryteria dla teorii pedagogicznego myślenia i działania. To powrót do pytań o to, jak organizować na nowo dzieciństwo, społeczeństwo, politykę i świat.

W Niemczech ukazał się odrębny zbiór rozpraw z tego zakresu, którego autorzy zastanawiają się, co należałoby rozumieć przez pedagogikę dekonstrukcyjną i do jakich problemów pedagogicznych odnosi się grono badaczy. Mimo rozwoju tego nurtu w łonie nauk o wychowaniu od przełomu lat 50. i 60. minionego stulecia jest on zatem coraz lepiej w nich reprezentowany i rozwijany, chociaż - jak wynika z mojej analizy - bliższy staje się współczesnej ideologii neolewicy. Warto przypomnieć, że kiedy powoli zanikała siła tej filozofii oraz ideologii w krajach Europy Zachodniej, pedagogika krytyczna zaistniała w krajach posttotalitarnych jako źródło odnowy humanistyki i praktyk edukacyjnych, które dość intensywnie poszukiwały nowych idei oraz form życia, w tym szczególnie swojego miejsca w społeczeństwach o gospodarce wolnorynkowej, neoliberalnej. Recepcja, a także aplikacje tej pedagogiki wiązały się przede wszystkim z przekładami na język polski, a następnie adaptacją teorii krytycznej Theodora W. Adorno, Maxa Horkheimera i Jürgena Habermasa do nauk o wychowaniu. Towarzyszył temu renesans idei wolności w wychowaniu początku XX stulecia, a wraz z nim - różnych modeli szkół pedagogiki reformy.

W krajach Europy Zachodniej wspomnianego okresu pedagogika krytyczna stała się zarówno obszarem formułowania krytyki różnych ideologii wychowania, jak i prospektywną teorią wyzwolenia człowieka poprzez edukację zgodnie zjego „interesem emancypacyjnym”. Poza pedagogiką Oświecenia nurt ten nawiązywał także do psychoanalizy, skupiając w dużej części wokół swojego modelu uprawiania pedagogiki tak zwaną Nową Lewicę zachodnioeuropejską, ale i amerykańską oraz francuską.

Przedstawicielom nauk krytycznych w pedagogice mojego pokolenia bliższa była ta perspektywa poznawcza, która traktowała emancypację jako naczelny cel instytucjonalnego wychowania. W niemieckim środowisku tego nurtu pedagogika Nowej Lewicy została zapoczątkowana wraz z odejściem ostatniego przedstawiciela pedagogiki duchowej, Ericha Wenigera, będąc zarazem symbolem sprzeciwu wobec tradycyjnej pedagogiki humanistycznej. Odrzucono ideę wychowania wspólnotowego - jako kojarzonego zokresem narodowego socjalizmu - zastępując ją ideą wychowania do solidarności z tymi, którzy znaleźli się w niekorzystnej dla siebie sytuacji życiowej, by pomóc im w pokonaniu trudności. Zgodnie z nową ideologią zastąpiono tezę o wrodzonym potencjale rozwojowym dzieci - niedostatecznymi 
osiągnięciami, które są wynikiem socjalizacji w niekorzystnych środowiskach społecznych (głównie dzieci z niższych klas społecznych w stosunku do dzieci z rodzin klasy średniej), wynikają także z różnic między chłopcami a dziewczętami, dziećmi ze środowisk wiejskich a tymi z miast, dziećmi z rodzin katolickich a ewangelickich i tak dalej. Osłabiono rolę kultury na rzecz nadwrażliwego doszukiwania się źródeł zła i przemocy wobec młodego pokolenia w uwarunkowaniach społeczno-politycznych jego edukacji oraz procesie wychowania. Punkt ciężkości przedstawicieli tego nurtu przesunął się z właściwej dla pedagogiki humanistycznej krytyki kultury na analizę społeczeństwa będącego źródłem ludzkich cierpień.

Pluralizm nurtów pedagogicznych stał się dla polskiej pedagogiki faktem, prowadząc do uznania trwałej niezależności różnych podejść do wychowania i kształcenia. Każda z pedagogii została niczym innym jak tylko jednym z wielu równorzędnych podejść do kształcenia oraz wychowania. Niestety nie analizuje się pluralizmu pedagogicznej myśli jako obiektywnego trwania obok siebie różnych prądów czy paradygmatów, tylko wprowadza się do debaty pochwałę lub negację tego stanu rzeczy. Niektórzy badacze nie dostrzegają lub celowo ukrywają fakt, iż w każdej dyscyplinie naukowej istnieje niejako równolegle wiele " "paradygmatów», czyli różnych tendencji czy nurtów, które podlegają różnego rodzaju oddziaływaniom wzajemnym i ciągle się przepostaciowują, tworząc coraz to nowe konfiguracje. $\mathrm{W}$ dodatku również $\mathrm{w}$ ramach tych tendencji czy nurtów występują bardzo istotne różnice związane z poszczególnymi koncepcjami (a w równej mierze i ze stylami wypowiedzi ich autorów), które sprawiają, że wszelkich prób nadawania im postaci jakiejś jedności często dokonuje się trochę na wyrost, albo też w sposób nieuzasadniony.”’

Wśród kilkudziesięciu (lub więcej) zróżnicowanych podejść do wychowania i kształcenia trudno mówić o ich tożsamym stanie historycznego zaistnienia, trwania oraz ewolucji, podobnym zakresie dostępności czy chociażby praktycznej aplikacji ${ }^{4}$. Z jednej strony powiada się o równości każdego paradygmatu, kierunku czy prądu pedagogicznego, w tym o równości prawa do istnienia wielu czy formułowanych dzięki temu preferencji oraz ojakże koniecznej obronie takiego radykalnego pluralizmu; z drugiej zaś strony rodzi to opór u tych, którzy uważają, że są przedstawicielami uniwersalnej prawdy, zobowiązującej ich do występowania przeciwko redukowaniu myśli do swobodnej, nieokiełznanej gry dyskursów jako zróżnicowanych „form językowych”, a prowadzącej w następstwie tych procesów do relatywizmu kulturowego i historycznego.

Pedagogika nie dysponuje, bo i dysponować nie może, jakimś metakryterium, które pozwalałoby na zdystansowane czy bezzałożeniowe badanie prądów oraz kierunków myśli o kształceniu i wychowaniu. Nie ma takiej miary, która uwalniałaby badacza od możliwego (koniecznego?) zaangażowania w ten proces własnej subiektywności. Nie dysponujemy takimi konstruktami teoretycznymi, za pomocą których moglibyśmy

\footnotetext{
${ }^{3}$ Paweł Dybel, Granice rozumienia i interpretacji. O hermeneutyce Hansa-Georga Gadamera (Kraków: Towarzystwo Autorów i Wydawców Prac Naukowych Universitas 2004), 154.

${ }^{4}$ Bogusław Śliwerski, Wspótczesna myśl pedagogiczna. Znaczenia. Klasyfikacje. Badania (Kraków: Oficyna Wydawnicza „Impuls” 2009).
} 
analizować wybrane czy wszystkie paradygmaty w sposób całkowicie bezosobowy, „z pozycji zupełnie pustego, abstrakcyjnego podmiotu, który jedynie relacjonuje «obiektywnie» to, co czyta, wziąwszy w nawias własną, określoną dziejowo perspektywę ich rozumienia. [...] nawet tak wybitny historyk filozofii, jakim był Władysław Tatarkiewicz, mający tak ogromne wyczucie dla odmiennych światów ludzkiej myśli, które badał, nie mógł ustrzec się szeregu uprzedzeń w prezentacji poglądów niektórych autorów." ${ }^{5}$

Zatem podstawowym założeniem komparatysty powinno być przeświadczenie, że żadnemu z paradygmatów czy nurtów nie przysługuje priorytet, nie powinien on zajmować centralnego miejsca i tym samym być punktem odniesienia dla pozostałych. Gdyby przyjąć, że pewne kategorie stricte pedagogiczne, jak: wychowalność (z wpisaną w nią kategorią oporu), wykształcenie (Bildsamkeit), oddziaływanie pedagogiczne (akt pedagogiczny), inicjacja, wspieranie rozwoju, towarzyszenie wzrastaniu, edukacja, stosunek wychowawczy, dyscyplina (oraz inne) stanowią rdzeń każdego paradygmatu i nurtu pedagogicznego, oddają ich istotę, są im wspólne, to wszystkie prądy i kierunki pedagogiczne zawierające jako kluczową jedną z tych właśnie kategorii byłyby sobie równe, gdyż wistocie ich przesłanie prowadziłoby do jednego celu, jakim jest proces wpisany w ów fenomen. Kategorie pedagogiczne są bowiem elementem realnej i/lub symbolicznej rzeczywistości pedagogicznej, stanowiąc w niej pewną całość, objaśniając proces wychowania czy kształcenia. Niewątpliwie taką kategorią pedagogiczną, która w ostatnich latach stała się przedmiotem zainteresowań badawczych, jest emancypacja. Nie oznacza to jednak, że pedagogika krytyczna mogłaby stać się metapedagogiką.

Niemiecki pedagog Hein Retter zwraca uwagę na wkład nauk krytyczno-emancypacyjnych w badanie stosunków władzy w relacjach między dziećmi a rodzicami czy uczniami a nauczycielami. Wychowanie postrzegane jest tu jako relacja, dominacji, panowania w stosunkach między starszymi a młodszymi. W nawiązaniu do eseju Theodora W. Adorno pt. Wychowanie po Oświęcimiu teoria krytyczna skupiała się nie na „dobru”, ale na „złu”. Tym samym i proces kształcenia był przedmiotem analiz oraz badań wnikających w istotę uwarunkowań społecznej egzystencji. „Pojęcie kształcenia odgrywało tu zasadniczą rolę w przeciwieństwie do pojęcia wychowania jako wolne od fenomenu panowania jednego człowieka (wychowawcy) nad innym (wychowankiem)."

Wychowanie do emancypacji występowało przeciwko władzy, zniewalaniu, opresji, uprzedmiotowieniu i autoalienacji winteresie oświecenia czy samostanowienia. Greckie emancipare oznacza przecież uwolnienie z ojcowskiej przemocy ${ }^{\top}$. W ujęciu prawnym kategoria emancypacji została rozszerzona na grupy społeczne, zatem także wychowanie miało sprzyjać emancypacji kobiet, a nawet dzieci. Emancypacja rozumiana była jako uwolnienie ludzi od ograniczeń, barier,

\footnotetext{
${ }^{5}$ Dybel, Granice, 126.

${ }^{6}$ Hein Retter, Grundrichtungen pädagogischen Denkens. Eine erziehungswsissenschaftliche Einführung (Bad Heilbrunn: Verlag Julius Klinkhardt 1997), 92 [tłumaczenie własne].

${ }^{7}$ Tamże, 93 .
} 
które uniemożliwiają im swobodny rozwój. To prawda, że dzięki temu pedagodzy zaczęli zwracać uwagę na zjawiska niesprawiedliwości społecznej, opresji, analizować autorytarne struktury społeczne, instytucjonalnie zaniedbujące określone, defaworyzowane grupy.

W latach 60. XX wieku koncepcje wychowania krytycznego powiązały proces wychowania $\mathrm{z}$ wyzwalaniem dzieci i młodzieży także z tabu seksualnego („,seksualnych norm obyczajowych”) oraz ze struktur autorytarnych w instytucjach edukacyjnych. Rolą wychowania miało być uwrażliwienie młodzieży na takie wartości jak sprawiedliwość czy równość, wolność myślenia oraz wypowiadania się, także wolność obyczajowa, problem stygmatyzacji osób z środowisk mniejszościowych. Szkoła miała sprzyjać uczeniu się podejmowania działań społecznych z satysfakcją oraz budowaniu relacji antyautorytarnych. Wraz z tym nurtem pojawiały się modele szkół zintegrowanych, jak i projekty edukacji zorientowanej na zainteresowania uczniów. Chętnie sięgano do szkół Nowego Wychowania oraz pedagogiki reformy (jak szkoły waldorfskie, freinetowskie, montessoriańskie, Planu Jenajskiego, Planu Daltońskiego oraz inne). Zdaniem Rettera niemiecka pedagogika krytyczno-emancypacyjna zupełnie pominęła psychologię, biologię (w tym antropologię) oraz takie nauki społeczne jak socjologia i nauki o polityce, a przecież zamierzano wyzwalać jednostki z opresji w życiu społecznym.

Pedagogika emancypacyjna jest nurtem normatywnym w naukach o wychowaniu, cechującym się zróżnicowanymi założeniami i strukturą, toteż biorąc pod uwagę występujące wśród jego przedstawicieli odmienne poglądy na istotę oraz rolę władzy czy autorytetu, rozumienie świata, istotę podmiotowości, jej rozwoju, a także zmiany społecznej i emancypacji człowieka, trzeba wskazać, że ma ona swoje odmiany. Maria Czerepaniak-Walczak dokonała interesującej rekonstrukcji korzeni pedagogiki emancypacyjnej, odnosząc współczesne teorie kształcenia i wychowania do nurtów filozofii krytycznej oraz jej społecznych „odnóg” (jak feminizm, ekologizm, ruchy narodowo-wyzwoleńcze czy pacyfistyczne) rozwijających się w latach 6o. XX wieku: „Tym, co je łączy, jest krytyka dominacji i uznanie interesu emancypacyjnego. Skupiają się więc na odkrywaniu źródeł przemocy, tkwiących w dziełach kultury oraz obyczajowych i politycznych wyznacznikach porządku społecznego, zarówno w czasach minionych, jak i we współczesności." ${ }^{8}$ Autorka wyróżnia trzy główne nurty w pedagogice emancypacyjnej: 1) nurt organizowania doświadczeń dobrowolnego uczestniczenia obywateli $\mathrm{w}$ różnym wieku w poszczególnych sferach życia demokratycznego, 2) pedagogikę wyzwolenia grup defaworyzowanych społecznie i ekonomicznie oraz 3) pedagogikę radykalną jako czynnik zmiany społecznej, instytucjonalnej, która jest „,...] nastawiona na odkrywanie i wdrażanie do edukacji związków refleksyjnego uczenia się, kształtowania krytycznych postaw i zachowań obywatelskich oraz rewitalizacji demokratycznej sfery publicznej."

\footnotetext{
${ }^{8}$ Maria Czerepaniak-Walczak, Pedagogika emancypacyjna. Rozwój świadomości krytycznej czlowieka (Gdańsk: Gdańskie Wydawnictwo Psychologiczne 2006), 45.

${ }^{9}$ Tamże, 75 .
} 
Rozprawa M. Czerepaniak-Walczak miała istotne znaczenie dla nauk pedagogicznych, bowiem stanowiła oryginalną koncepcję teoretyczną oraz praktyczną kształcenia i wychowania emancypacyjnego. Niestety nigdy nie została ona uwzględniona przez polityczne władze w III RP (Ministerstwo Edukacji Narodowej) ze względu - jak sądzę - na niewłaściwy moment jej ukazania się: wydana w roku 2006 natrafiła na okres przejęcia władzy przez formację prawicową z ministrem Romanem Giertychem na czele. Ówczesna koalicja rządząca (Prawa i Sprawiedliwości, Samoobrony oraz Ligi Polskich Rodzin) nie była zainteresowana rozwijaniem czy wspomaganiem $\mathrm{w}$ toku edukacji szkolnej kompetencji emancypacyjnych dzieci i młodzieży, wtym zdolności do krytycznej oceny rzeczywistości, odwagi oraz innowacyjności. Ortodoksyjni konserwatyści nie chcieli uwalniania edukacji szkolnej od dogmatów, oficjalnej wykładni ładu, porządku, dyscypliny, posłuszeństwa, bezpieczeństwa, dlatego konstruowali swój model kształcenia i nadzoru pedagogicznego, bazujący na marginalizowaniu czy ograniczaniu swobód uczniowskich, rodzicielskich, nauczycielskich oraz na wprowadzaniu różnych form przemocy władzy wobec nauczycieli ${ }^{10}$.

Paradygmat krytyczny nie wszedł zatem do kanonu celów i zasad kształcenia ogólnego, natomiast był i nadal jest rozwijany w środowisku alternatyw edukacyjnych szkolnictwa publicznego początku lat 90. ${ }^{11}$ oraz przez cały ten okres w niektórych typach i modelach szkół niepublicznych ${ }^{12}$. Najlepszym przykładem konsekwentnego przejścia od

${ }^{10}$ Zob. Wychowanie. Pojęcia. Procesy. Konteksty. Interdyscyplinarne ujęcie, red. Maria Dudzikowa, Maria Czerepaniak-Walczak, tom 4 (Gdańsk: GWP 2008); Bogusław Śliwerski, Pedagogika dziecka. Studium pajdocentryzmu (Gdańsk: Gdańskie Wydawnictwo Psychologiczne 2007).

${ }^{11}$ Zob. Bogumiła Dumowska, Edukacja autorska $w$ szkołach publicznych $w$ Polsce (Kraków: Oficyna Wydawnicza „Impuls”, 2003); Edukacja w wolności, red. Bogusław Śliwerski (Kraków: Oficyna Wydawnicza Impuls 1992); Edukacja alternatywna XXI wieku, red. Bogusław Śliwerski, Zbyszko Melosik (Kraków: Oficyna Wydawnicza „Impuls” 2010); Monika Figiel, Szkoły autorskie w Polsce. Realizacje edukacyjnych utopii (Kraków: Oficyna Wydawnicza „Impuls” 2001); Konstruowanie autorskich programów kształcenia stymulujących i wspierających rozwój uczniów we wspótczesnej szkole, red. Janusz Gnitecki (Poznań: Biuletyn Polskiego Towarzystwa Pedagogicznego Oddział w Poznaniu 2004); Beata Przyborowska, Struktury innowacyjne w edukacji. Teoria. Praktyka. Rozwój (Toruń: Wydawnictwo Naukowe UMK 2003); Bogusław Śliwerski, Wyspy oporu edukacyjnego (Kraków: Oficyna Wydawnicza „Impuls”, 1993, II wyd. 2009); tegoż, Edukacja autorska (Kraków: Oficyna Wydawnicza „Impuls” 1996, II wyd. 2009); tegoż, Jak zmieniać szkotę? (Kraków: Oficyna Wydawnicza „Impuls” 1998, II wyd. 2009); tegoż, Edukacja pod prąd, (Kraków: Oficyna Wydawnicza „Impuls”, Kraków 2001, II wyd. 2009); tegoż, Problemy wspótczesnej edukacji. Dekonstrukcja polityki oświatowej III RP, (Warszawa: WAiP 2009).

${ }^{12}$ Zob. Renata Brzezińska, Artur Brzeziński, Idee angielskiej wolnej szkoły Summerhill w polskich egzemplifikacjach (Włocławek: Wydawnictwo Wyższej Szkoły Humanistyczno-Ekonomicznej we Włocławku 2012); Ryszard Łukaszewicz, Edukacja z wyobraźniq czyli jak podróżować bez map (Wrocław: Wydawnictwo Uniwersytetu Wrocławskiego 1994); tegoż, „Leczenie ghupoty” i... czyli Salony Edukacji Ekologicznej NATURAmy (Wrocław: Wydawnictwo Uniwersytetu Wrocławskiego 1996); Ryszard Łukaszewicz, Szkoła jako kawałek innego świata (Wrocław: FWIE 1997); tegoż, Studia nad alternatywami w edukacji (Wrocław: Fundacja Wolne Inicjatywy Edukacyjne 2002); tegoż, Wrocławska Szkoła Przyszłości. Dla duchowości, dla wyobraźni, dla praktyki... z nieoczekiwanq przypowieściq autobiograficzna (Wrocław: Fundacja Wolne Inicjatywy Edukacyjne 2011); Aleksander Nalaskowski, Szkoła jako opus dei. Liceum Ogólnokształcace PW „Poltech” (Torun: PW „Poltech” 1991); tegoż, Edukacja, która nie chce przeminać (Kraków: Oficyna Wydawnicza „Impuls” 1999); tegoż, Widnokregi edukacji (Kraków: Oficyna Wydawnicza „Impuls” 2002); Wrocławska Szkoła Przysztości. Przesłanki eksperymentu nad szkoła, red. Ryszard 
kontestacji do edukacji było powołane do życia przez Krystynę Starczewską I Liceum Społecznego na ulicy Bednarskiej w Warszawie. Jest ono szkołą demokratyczną, która nie tylko wyrosła z zaangażowania jej założycielki w opozycję demokratyczną oraz organizowane przez nią w Towarzystwie Kursów Naukowych wykłady i prowadzone seminaria dla nauczycieli, społeczników, naukowców na temat pedagogiki oraz psychologii humanistycznej wokresie PRL, ale stanowiła odpowiedź na dysfunkcje polskiego szkolnictwa, a także polityki oświatowej, formę protestu przeciwko działalności szkół publicznych i kierujących nimi ludzi. Jak sama o tym mówi w jednym z wywiadów: „Można powiedzieć, że to wszystko razem było w swej istocie działaniem kontrkulturowym, jeśli za oficjalną kulturę uznać establishment komunistyczny i rządy ideologiczne. Prowadzone przez nas niezależne spotkania, niezależne dyskusje, niezależne badania na szeroką skalę nie tylko w zamkniętym środowisku akademickim, ale także wychodzące na zewnątrz były tworzącym się spontanicznie kontrkulturowym ruchem społecznym."13

Pedagogika krytyczna jako myśl, idea, prąd pedagogiczny przenikała jednak do niektórych subdyscyplin nauk o wychowaniu. W pedagogice społecznej dokonała tego Danuta Urbaniak-Zając, która opublikowała monografię naukową poświęconą myśli pedagogiki społecznej w Niemczech. Trafnie w niej odnotowała, że z amerykańskiej polityki społecznej przenikały na nasz kontynent głównie rozwiązania o charakterze praktycznym, związanym zoptymalizacją działań pomocowych wśrodowiskach społecznych oraz diagnozy wnikające głównie wpsychologiczne uwarunkowania sytuacji problemowych czy natury organizacyjno-technicznej. Uczulała nas na to, byśmy nie powtórzyli błędu naukowców po zachodniej stronie granicy, gdzie niektórzy pedagodzy społeczni bezrefleksyjne przejmowali amerykańskie wzory. Współpracujący z nią i doświadczeni w tym zakresie badacze zwracali zatem uwagę na to, iż owe wzory nie są ,adekwatne do struktury organizacyjnej niemieckiej pomocy społecznej oraz że nie są wcale oryginalne." 14

Jak wskazuje łódzka pedagog społeczna, rozwój pedagogiki krytycznej w Niemczech zmierzał między innymi do zrezygnowania z kategorii „pedagogicznej odpowiedzialności" wychowawcy za wychowanka na rzecz odpowiedzialności za krytyczny potencjał społeczeństwa, do którego wzmocnienia miała prowadzić także edukacja szkolna. Sprzyjało to eksponowaniu przez badaczy negatywnych skutków mechanizmów społecznych, które ograniczają rozwój jednostki, ale pomijało czy przesuwało na bok zainteresowanie również samą jednostką jako istotą także przecież kreującą siebie, a unikającą w tym kontekście odpowiedzialności za skutki własnych działań. Wartościowa

Łukaszewicz (Wrocław: Acta Universitatis Wratislaviensis No 396, Prace Pedagogiczne XIII, 1978); Wrocławska Szkoła Przyszłości. Autonomia dziecka w procesie edukacji, red. Ryszard Łukaszewicz (Wrocław: Acta Universitatis Wratislaviensis No 851, Prace Pedagogiczne LVII 1987).

${ }^{13}$ Krystyna Starczewska, „Światopoglądy. Rozmowa 02. Rozmawiali Aldona Jawłowska i Aleksander Wasiliew”, w: Wolność w systemie zniewolenia. Rozmowy o polskiej kontrkulturze, red. Aldona Jawłowska, Zofia Dworakowska (Warszawa: Uniwersytet Warszawski, Instytut Stosowanych Nauk Społecznych 2008), 77.

${ }^{14}$ Danuta Urbaniak-Zając, Pedagogika spoleczna $w$ Niemczech. Stanowiska teoretyczne i problemy praktyki (Łódź: Wydawnictwo Uniwersytetu Łódzkiego 2003), 107. 
natomiast dla tej pedagogiki okazała się amerykańska teoria naznaczania społecznego, która odsłoniła nowe perspektywy poznawania i interpretowania zachowań antyspołecznych czy niedostosowania społecznego. „Amerykańskie koncepcje naznaczania społecznego pokazały zjednej strony, że treść obowiązujących norm jest produktem społecznym, a z drugiej, że decyzja o tym, czy przekroczenie normy miało miejsce, czy nie, jest rezultatem społecznego procesu interakcji i podjętej decyzji." 15

Mamy znakomitą tradycję badań nad oporem w edukacji i wobec edukacji, którą rozwija za Lechem Witkowskim słupska pedagog ogólna Ewa Bilińska-Suchanek ${ }^{16}$. W swojej pierwszej monografii uczyniła punktem wyjścia własnych badań krytyczną teorię społeczną jako tę, która najlepiej umożliwia opisywanie oraz analizę wciąż w naszym kraju autorytarnej rzeczywistości szkolnej. W krytycznej teorii społecznej badaczka odnalazła filozoficzne podstawy poznania i zrozumienia mechanizmów dominacji oraz posłuszeństwa wstrukturach społecznych, dostarczając tym samym wiedzy i rozbudzając autorefleksję u pedagogów, a także wolę walki w interesie jednostkowego oraz społecznego upełnomocnienia osób uczących się i je kształcących. Uświadomienie sobie przez jednostkę dialektyki wolności i przymusu może stworzyć większe możliwości jej upełnomocnienia i emancypacji. Szkoła jest jednym ztych środowisk, wktórych pojawiają się zarówno dominacja/panowanie, jak i wyzwolenie/upełnomocnienie.

Rekonstruując podstawowe przesłanki teoretyczne pedagogiki oporu, autorka sięga po właściwą dla niej perspektywę epistemologiczną, której założenia mają daleko idące konsekwencje praktyczne. Słupska pedagog odwołuje się przy tym do współczesnych filozofów czy socjologów krytycznych (H. Giroux, M. Young, B. Murchland, P. McLaren, L. Grossberg, P. Bourdieu, J.C. Passeron, M. Foucault) oraz do rozpraw współczesnych badaczy tego nurtu w Polsce, takich jak Lech Witkowski ${ }^{17}$, Zbigniew Kwieciński ${ }^{18}$, Tomasz

15 Tamże, 128.

${ }^{16}$ Ewa Bilińska-Suchanek, Opór wobec szkoly. Dorastanie w perspektywie paradygmatu oporu. Studium socjopedagogiczne (Słupsk: Pomorska Akademia Pedagogiczna w Słupsku 2000); tejże, Nauczyciel i opór (wobec) systemu edukacji (Toruń: Wydawnictwo Adam Marszałek 2013).

${ }^{17}$ Lech Witkowski, „Śmiech jako opór i wyzwolenie (pogranicze wiedzy, wiary i władzy)”, w: Nieobecne dyskursy, red. Zbigniew Kwieciński, cz. 1 (Toruń: Studia Kulturowe i Edukacyjne 1991); tegoż, „Wokół teorii i praktyki rytuałów szkolnych”, w: Nieobecne dyskursy, red. Zbigniew Kwieciński, cz. 2 (Toruń: Wydawnictwo Uniwersytet Mikołaja Kopernika 1992); tegoż, „W kręgu pedagogiki radykalnej (dekonstrukcja, walka, etyczność)", w: Spory o edukację. Dylematy $i$ kontrowersje we wspótczesnych pedagogiach, red. Zbigniew Kwieciński, Lech Witkowski (Warszawa: IBE 1993).

${ }^{18}$ Zbigniew Kwieciński, Socjopatologia edukacji (Warszawa: IRWiR PAN 1992); tegoż, Tropy ślady - próby. Studia i szkice z pedagogiki pogranicza (Poznań-Toruń: Wydawnictwo Edytor 2000); tegoż, Między patosem a dekadencją. Studia i szkice socjopedagogiczne (Wrocław: Wydawnictwo Naukowe DSWE TWP 2007); tegoż, Dylematy. Inicjatywy. Przebudzenia. Nad przestankami odrodzenia edukacji w Polsce (Wrocław: Wydawnictwo Naukowe DSW 2011); tegoż, Cztery i pół. Preliminaria. Liminaria. Varia (Wrocław: Wydawnictwo Naukowe DSW 2011). 
Szkudlarek $^{19}$, Bogusław Śliwerski ${ }^{20}$, Zbyszko Melosik ${ }^{21}$ czy Maria Dudzikowa $^{22}$. Jej rozprawa wzbudziła ogromne zainteresowanie w naszym środowisku, gdyż zachęciła kolejnych badaczy do wchodzenia w spór o zakres i rolę występujących w szkołach zjawisk oporu. Nareszcie zostały ukazane różne jego wymiary, zarówno te negatywne - w codziennym środowisku życia uczniów oraz w konstruowaniu procesów edukacyjnych przez pedagogów, jak i pozytywne - emancypacyjne.

Autorka dokonała zawężenia problemu badań do rodzajów oporu wynikającego z postaw uczniów wobec szkoły jako instytucji nad nimi dominującej. Szczególnie cenne okazało się jej twórcze rozwinięcie typologii oporu H.A. Giroux poprzez wzbogacenie jej o trzeci wymiar, jakim jest poziom zaangażowania w opór oraz komponent procesu ambiwalencji (emulacja, mimetyzm czy opozycja). Szkoda wprawdzie, że z pewnymi typologiami czy kategoriami definicyjnymi tego pojęcia nie polemizuje (jak chociażby z propozycją rozróżnienia oporu od kontestacji według J.V. Fernandesa), przyjmując za właściwe stwierdzenie, iż „kontestacja ma charakter reproduktywny” ${ }^{23}$. Tak się składa, iż plonem polskiej debaty nad istotą kontestacji w polskiej pedagogice w czasie I Ogólnopolskiego Zjazdu Pedagogów w Rembertowie w 1993 roku w ramach kierowanej przeze mnie sekcji „Kontestacje pedagogiczne”24 było ukazanie transformatywnej roli tego fenomenu. Kontestacja to przecież zakwestionowanie obowiązującej słuszności, prawomocności, „ruszenie martwej struktury”25, uwalnianie się od starych schematów ${ }^{26}$, radykalna zmiana w sposobie postrzegania rzeczywistości ${ }^{27}$, nie można więc godzić się na takie jej przeciwstawienie kategorii oporu, które umieszczałoby kontestację na pozycji inhibitora zmian. Łacińskie contestari, contestor

${ }^{19}$ Tomasz Szkudlarek, Bogusław Śliwerski, Wyzwania pedagogiki krytycznej i antypedagogiki (Kraków: Oficyna Wydawnicza „Impuls” 1991); Tomasz Szkudlarek, „McLaren i Agata: o pewnej możliwości interpretacji rytualnego oporu przeciw szkole", w: Nieobecne dyskursy, red. Zbigniew Kwieciński, cz. 2 (Toruń: Studia Kulturowe i Edukacyjne 1992); tegoż, Wiedza i wolność w pedagogice amerykańskiego postmodernizmu (Kraków: Oficyna Wydawnicza „Impuls” 1993); tegoż, „Pedagogika krytyczna”, w: Pedagogika. Podręcznik akademicki, red. Zbigniew Kwieciński, Bogusław Śliwerski, tom I (Warszawa: WN PWN 2003); Różnica, tożsamość, edukacja. Szkice z pogranicza, red. Tomasz Szkudlarek (Kraków: Oficyna Wydawnicza „Impuls” 1995).

${ }^{20}$ Bogusław Śliwerski, „Kontestacja pedagogiki końca XX wieku”, w: Nieobecne dyskursy, cz. 1, red. Zbigniew Kwieciński (Toruń: Wydawnictwo UMK 1991); tegoż, Przekraczanie granic wychowania. Od „pedagogiki dziecka" do antypedagogiki, Acta Universitatis Lodziensis, Folia Paedagogica et Psychologica, (Łódź: Wydawnictwo Uniwersytetu Łódzkiego 1992); tegoż, „Pedagogika krytyczna”. Szkoła Zawodowa 10 (1992); tegoż, „Antypedagogika”. Kwartalnik Pedagogiczny 1(1990); Sliwerski, Wyspy oporu; Śliwerski, Jak zmieniać; Śliwerski, Wspótczesne teorie; Śliwerski, Współczesna myśl.

${ }^{21}$ Zbyszko Melosik, Tomasz Szkudlarek, Kultura, tożsamość i edukacja. Migotanie znaczeń (Kraków: Oficyna Wydawnicza „Impuls” 1998).

${ }^{22}$ Maria Dudzikowa, Mit o szkole jako miejscu wszechstronnego rozwoju ucznia. Eseje etnopedagogiczne (Kraków: Oficyna Wydawnicza „Impuls” 2001).

${ }^{23}$ Bilińska-Suchanek, Opór, 64.

${ }^{24}$ Kontestacje Pedagogiczne, Materiały III Sekcji Zjazdu Pedagogów, red. i wstęp Bogusław Śliwerski, (Warszawa: ZG PTP, Oficyna Wydawnicza „Impuls“ 1993).

${ }^{25}$ Jadwiga Staniszkis, Postkomunizm. Próba opisu (Gdańsk: słowo/obraz terytoria 2001).

${ }^{26}$ Aldona Jawłowska, Drogi kontrkultury (Warszawa: Państwowy Instytut Wydawniczy 1975).

${ }^{27}$ Kontestacje. 
to zaprzeczenie a jednocześnie potwierdzenie wartości, w imieniu których coś zostało zanegowane.

Dyskusyjna jest także normatywnie skonstruowana przez E. BilińskąSuchanek teza, że szkoła może być terenem kształtowania się kompetencji komunikacyjnych uczniów wich relacjach z nauczycielami zgodnie z modelem dyskursu J. Habermasa. Jak pisze: „Nauczyciel i uczeń tylko wówczas będą mogli osiągnąć «prawdziwy konsensus», gdy na czas rozmowy zawieszą hierarchię szkolną. Pełna symetryczność relacji pomiędzy uczestnikami dyskursu ma oznaczać takie samo prawo do spełniania aktów mowy, jak i do kwestionowania podnoszonych wraz z nimi roszczeń do ważności." ${ }^{\text {28 }}$ Zdaniem Habermasa dyskurs komunikacyjny nie może brać pod uwagę tylko intencji argumentujących podmiotów, ale i racjonalność struktur społecznych, w ramach których ma miejsce proces wymiany argumentów. Trudno jest przecież o uzyskanie porozumienia tam, gdzie struktura społeczna zakłada dychotomiczny podział ról na tych, którzy mają prawo mówić i tych, którym wolno jedynie słuchać czy na tych, którzy mogą wydawać polecenia i pouczać innych oraz tych, których jedynym „prawem” jest obowiązek posłuszeństwa.

$\mathrm{Z}$ teoretycznych ram kategorialnych działan komunikacyjnych Habermasa wynika wyraźnie, że nie występują w nich takie centralne pojęcia pedagogiczne jak wychowanie, kształcenie czy nauczanie. Sam Habermas pisze o interakcjach socjalizacyjnych, a nie o działaniach pedagogicznych, które zakładają asymetrię między wychowawcą a wychowankiem. Działania te muszą bazować na czasowej asymetrii w zakresie wiedzy i umiejętności podmiotów edukacji szkolnej. Udoskonalić można kogoś tylko wówczas, kiedy podlega on relacjom pod- i nadrzędności, pedagog zaś działa w imieniu wychowanka jako rzecznik jego interesów; naucza go, by umożliwić mu uczenie się; wychowuje, by ułatwiać mu samowychowanie. Wartość teorii krytycznej J. Habermasa dostrzegałbym zatem nie tyle w możliwości jej zastosowania do przekształcania stosunków społecznych między nauczycielami a uczniami, ale do rozpoznawania prawomocności kontekstu normatywnego działań i definicji sytuacji wychowawczych będących wytworem wszystkich nauczycieli w danej placówce.

Należałoby sobie zadać pytanie, czy szkoła jest wspólnotą edukacyjną, jeśli procesy kształcenia i wychowania nie są kreowane przez wspólnotę nauczycieli traktujących edukację jako wspólne zadanie, jeśli nie powstają one w dialogu i partnerstwie uzgadniania zasad ich generowania, jeśli nie ma wśród samych pedagogów porozumienia oraz wzajemnego poszanowania. Młodzież szkolna wypowiada swoim nauczycielom posłuszeństwo i kwestionuje normatywny układ odniesienia skierowanych na nią oddziaływań pedagogicznych właśnie dlatego, że doświadcza nie tyle własnego kryzysu tożsamości, ile tegoż kryzysu u swoich pedagogów oraz braku ich kompetencji komunikacyjnych. Nie bardzo czytelne i nie do końca zrozumiałe jest wyróżnianie obok siebie przez E. Bilińską-Suchanek trzech pedagogii - pedagogiki oporu, pedagogiki krytycznej i pedagogiki radykalnej - jako

\footnotetext{
${ }^{28}$ Bilińska-Suchanek, Opór, 31.
} 
zupełnie odrębnych. W świetle dokonanej w pracy analizy ewolucji idei i prądów społecznych pedagogika radykalna jawi się jako badająca instytucję szkoły głównie z perspektywy odzwierciedlania przez nią dominującego społeczeństwa, postrzegania nauczycieli jako funkcjonariuszy, a uczniów jako ofiar ich oddziaływań ${ }^{29}$.

Pedagogika oporu tworzy - jej zdaniem - ,język nadziei”, kiedy postrzega szkołę jako miejsce otwarcia na konflikt, kontestację i autokreację jej podmiotów edukacyjnych, proponując odejście od myślenia deterministycznego ${ }^{30}$. Pedagogika krytyczna zaś wprowadza do obiegu publicznego ,język krytyki”, demistyfikuje dominujące ideologie oraz praktyki społeczne, które, niosąc przemoc i dominację, upowszechniają postawy przetrwania oraz bierności. Ich uświadomienie mobilizuje potencjał emancypacyjny ${ }^{31}$.

Można jednak zapytać, czym się różni poznawcza atrakcyjność i odmienność podejścia aplikacyjnego do kategorii oporu w tych trzech nurtach? Jak się one mają do problematyki badawczej nowej socjologii edukacji, której przedstawiciele przejmowali problemy badawcze pedagogów oraz wysuwali postulaty niehierarchicznej formy pedagogiki szkolnej? Sądzę, że zamiast mówić o trzech pedagogiach (krytycznej, radykalnej i oporu), trafniejsze byłoby przyjęcie za Yves Bertrandem ${ }^{32}$, iz mamy tu do czynienia z pedagogiką krytyczną, która integruje w sobie wyniki badań między innymi nad kategorią oporu na przecięciu trzech nurtów teoretycznych: ortodoksyjnego marksizmu (S. Bowles, H. Gintis, M. Apple, E. Ellsworth, S. Aronowitz, P. Bourdieu, J.C. Passeron, W.B. Stanley, H. Giroux), nowej socjologii edukacji (M. Young) i studiów kulturowych („cultural studies”: J. Habermas, T.W. Adorno, H. Marcuse, F. Pollock, L. Löwenthal, E. Fromm, L. Althuser, G. Deleuze, F. Guattari, J. Baudrillard i M. Foucault).

Niezaprzeczalnym wkładem w polską pedagogikę krytyczną E. BilińskiejSuchanek jest przeprowadzenie przez nią badań empirycznych na próbie liczącej łącznie 1090 uczniów z 26 szkół ponadpodstawowych i pomaturalnych, które odsłaniają słabości oddziaływań współczesnej szkoły średniej na młodzież w jej jakże znaczącym dla kształtowania się tożsamości okresie życia. Badania nad oporem w edukacji szkolnej odkrywają głębokie zróżnicowanie postaw sprzeciwu uczniów wobec tej instytucji oraz wskazują na potrzebę jak najszybszego przeanalizowania takich postaw wśród samych nauczycieli. Badana młodzież okazała się ambiwalentna w swoim oporze wobec nauczycieli, a największy okazał się opór akomodacyjny, bierny i agresywny wobec grona pedagogów $!^{33}$ Ujawnione zostały zjawiska, które stawiają pod znakiem zapytania sens prowadzenia zasadniczych i średnich szkół zawodowych, gdzie dominują nauczyciele bezradni wobec problemów młodzieży uczącej się, generujący opór bierny, a nawet agresywny (wandalizm, ucieczki z lekcji

\footnotetext{
${ }^{29}$ Tamże, 53 i n.

${ }^{30}$ Tamże, 40-41.

${ }^{31}$ Tamże, 39.

${ }^{32}$ Yves Bertrand, Soudobé teorie vzdělávání, přel. Oldřich Selucký (Praha: Portál, s. r. o. 1998).

${ }^{33}$ Tamże, 132-135.
} 
oraz przestępczość) czy prowadzący do wysokiego wskaźnika marginalizacji uczniów. Wnioski z analizy ilościowo-jakościowej brzmią alarmująco: „Nauczyciele w szkole jako systemie społecznym są bezpośrednią przyczyną wycofywania się młodzieży z naturalnego, otwartego i zewnętrznego oporu typu transformatywnego i wchodzenia w opór wewnętrzny typu akomodacyjnego, biernego i agresywnego."34

Przytoczone liczby i współczynniki korelacji tak niepokojących zjawisk, jak wycofywanie się młodziė̇y z dyskursu z nauczycielami, z autentycznego porozumiewania się z nimi, rezygnowanie $\mathrm{z}$ otwarcia się wobec nich aż po pozorowanie lojalności i aktywności, alarmują o jak najszybszą reformę szkolnictwa ponadpodstawowego. Nie chodzi tu jednak o transformację programową czy strukturalną, ale o kulturową zmianę wobszarze współczynnika humanistycznego szkoły w środowisku nauczycielskim. Dzięki przyjęciu przez słupską pedagog szerokiego zakresu diagnozowanych zmiennych niezależnych otrzymaliśmy bardzo rzetelny obraz rozkładu postaw oporu uczniów wobec szkoły i procesów edukacyjnych w korelacji z ich sytuacją rodzinną, pozycją społeczną w klasie szkolnej czy miejscem zamieszkania (miasto - wieś). Powyższe dane empiryczne nie wywołały jednak chociaż powinny - wstrząsu w polskim społeczeństwie, zwłaszcza wśród nauczycieli szkolnictwa ponadgimnazjalnego, by obudziło się z letargu i budowanego latami przyzwolenia na nietykalność czy obojętność wobec postaw pesudopedagogicznych dużej jego części (jak się okazuje) na tym szczeblu kształcenia. Cała rozprawa mogła być silnym argumentem, nie tylko dla MEN, na rzecz potrzeby przeprowadzenia głębokiej i rzeczywistej reformy w tym środowisku szkolnym! Uzyskane wyniki badań stają się niewątpliwie ważnym wkładem poznawczym w „odbrązowienie” wciąż idealizowanego w naszym kraju stanu kondycji osobowościowej nauczycieli, zachęcając do dyskusji na temat jego słabości, źródeł konfliktów, zagrożeń rozwojowych czy braków kompetencyjnych. Co ważne, są one kontynuowane przez kolejne, młode pokolenie pedagogów krytycznych ${ }^{35}$.

Ten rodzaj dyskursu pojawia się w każdym społeczeństwie, zarówno totalitarnym czy monistycznym (monoideologicznym, monowyznaniowym, monoświatopogloądowym), jak i otwartym, pluralistycznym. Kiedy mówimy o kontestacji, najczęściej łączymy czy kojarzymy ją z czymś negatywnym, niedopuszczalnym, niewłaściwym, a więc z jakąś alternatywą, której zwolennicy sami sytuują się w dualistycznie konstruowanym czy definiowanym świecie poza jego nawiasem, poza dopuszczaną w nim normą czy granicami tolerowanych postaw i zachowań. Jak piszą redaktorki tomu poświęconego polskiej kontrkulturze w czasach systemu zniewolenia: „Termin «kontrkultura» używany jest w różnych znaczeniach. W sposobach jego definiowania wyodrębnić można dwa główne kierunki. Pierwszy z nich reprezentują badacze, traktujący kontrkulturę jako zjawisko obecne w różnych epokach historycznych - każda kultura ma swą kontrkulturę. Należy do nich Umberto Eco, a także John M. Yinger; wedle niego kontrkultura to «zbiór norm i wartości pewnej

\footnotetext{
${ }^{34}$ Bilińska-Suchanek, Opór, 269.

${ }^{35}$ Sławomir Pasikowski, Ambiwalencja iopór. Nauczyciele istudenci wobec szkoły (Słupsk: Wydawnictwo Akademii Pomorskiej w Słupsku 2014).
} 
grupy społecznej, które w wyrazisty sposób kłócą się z normami i wartościami społeczeństwa, którego owa grupa jest częścią». Dodać tu trzeba, że owe wartości, początkowo przypisane "pewnej grupie», stają się zwykle podstawą budowania utopijnych wizji lepszego świata. Definicje tego rodzaju nie przesądzają ani o zawartości «zbioru», ani o tym, jakie wartości i normy zostały zakwestionowane.

Kierunek drugi nazwę «kontrkultura» lączy z konkretnym miejscem i czasem, obejmując nią ruchy młodzieży, które w końcu lat sześćdziesiątych ogarnęły Amerykę i wszystkie niemal kraje Europy. W ramach tego kierunku mieszczą się więc definicje, których podstawą jest wyodrębnienie najważniejszych, specyficznych, a zarazem wspólnych cech ruchu. Najbardziej znanym reprezentantem takiego myślenia jest twórca terminu «kontrkultura», Theodore Roszak." ${ }^{36}$ W tym drugim znaczeniu kontrkulturę pojmuje się albo jako ruch zmierzający do radykalnej zmiany w obszarze szeroko pojmowanej kultury, albo jako ruch polityczny dezawuujący system społeczno-polityczny w danym społeczeństwie i dążący do jego zmiany lub do uzyskania wjego strukturze prawa do preferowania i wyrażania własnych a odmiennych wobec niego postaw politycznych.

Kontrkultura pojawiała się w Polsce jako nurt intelektualny także w środowisku akademickim, głównie wśród młodych naukowców, którzy kwestionowali dominujące wzory uprawiania nauk humanistycznych oraz społecznych; byli wśród nich pedagodzy podważający rozwiązania dominujące w systemie edukacji, opieki czy wychowania młodych pokoleń. Zapewne można w obrębie polskiej kontrkultury wyróżniać różne jej odcienie, których kreatorom udało się (paradoksalnie) bez szczególnie negatywnych konsekwencji wcisnąć w szczeliny systemu i jeśli ich nawet w pełni nie zrealizowali, to przynajmniej otworzyli ścieżkę dostępu do wiedzy o nich, ich założeniach, o projektach ciekawych, ważnych, nowatorskich, choć niestety jeszcze nierealizowalnych. W pedagogice niewątpliwie taką rolę spełniały znakomicie opracowane w interdyscyplinarnym zespole naukowców założenia Wrocławskiej Szkoły Przyszłości Ryszarda Łukaszewicza ${ }^{37}$, która mogła zaistnieć jako dopuszczalny model edukacji dopiero po zmianie ustroju. Słusznie też redaktorki wspomnianego powyżej tomu piszą o tym, że niektórzy twórcy alternatywnych rozwiązań czy zjawisk kontrkulturowych sami ich tak nie identyfikowali czy też nie nazywali, a mimo to, kreując je, potwierdzali, że mają one taki właśnie charakter.

Zakwestionowanie pewnego systemu normatywnego oraz obyczajowego przez kontestatora zawsze ożywiało w Polsce myśl krytyczną w sferze filozoficznej, aksjonormatywnej, wprowadzało nowe pojęcia i język, a tym samym wymuszało konstruowanie innych narzędzi do prowadzenia badań tych zjawisk, wyznaczając

\footnotetext{
${ }^{36}$ Zofia Dworakowska, Aldona Jawłowska, „Wstęp”, w: Wolność w systemie zniewolenia. Rozmowy o polskiej kontrkulturze, red. Aldona Jawłowska, Zofia Dworakowska (Warszawa: Uniwersytet Warszawski. Instytut Stosowanych Nauk Społecznych 2008), 7-8.

${ }^{37}$ Łukaszewicz, Edukacja; Łukaszewicz, Leczenie ghupoty; Łukaszewicz, Szkoła; Łukaszewicz, Wroctawska.
} 
zarazem nowe funkcje społeczne nauk humanistycznych i społecznych ${ }^{38}$. Pedagogiczna kontrkultura wyrastała z zupełnie innych powodów, na innych podstawach, niż ta wiązana z ruchami zachodniej kontestacji politycznej, artystycznej czy społecznej. W moim przekonaniu była jej naturalnym źródłem, które w okresie totalitarnego PRL władze polityczne poddawały cenzurze oraz radykalnie ograniczały dostęp, lecz mimo to dzięki osobistym, często rodzinnym, bezpośrednim lub pośrednim kontaktom niektórych naukowców z przedstawicielami świata nauki czy ich wyjazdom zagranicznym do wolnych krajów oraz dzięki niezakwestionowaniu pedagogiki porównawczej w naukach o wychowaniu (choć nie ulega wątpliwości, że była ona mocno ograniczana przez cenzurę), mogła rozwijać się w nurcie alternatywna pedagogika, pedagogika kontestacji dominujących modeli kształcenia czy/i wychowania.
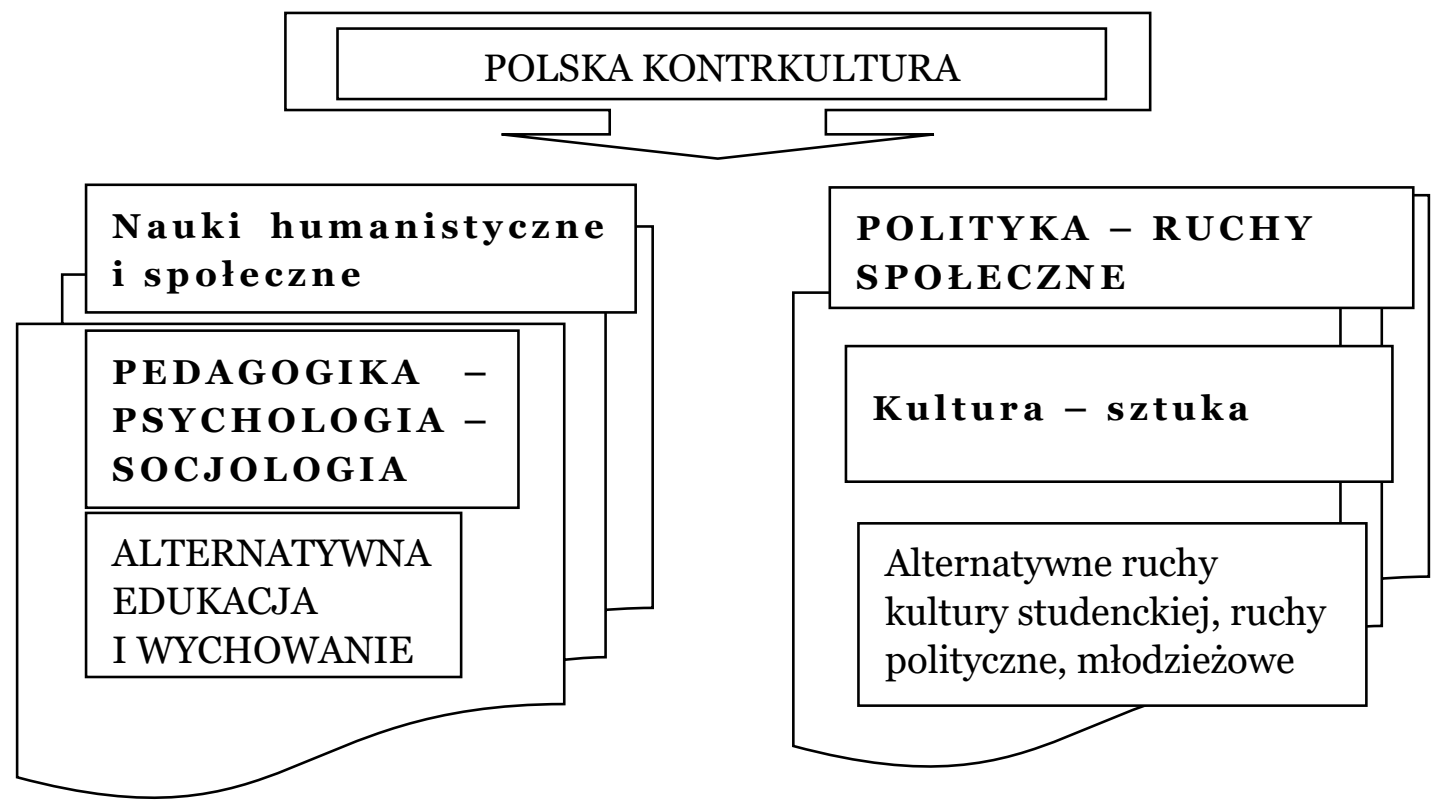

Schemat 1. Struktura polskiej kontrkultury społeczno-politycznej i kulturowej (źródło: opracowanie własne)

Dla pedagogiki, która była jedną z najsilniej poddawanych światopoglądowej indoktrynacji nauk humanistycznych, przełomowe były próby wyzwalania się $\mathrm{z}$ dominującego paradygmatu pozytywistycznego i marksistowskiego zarazem, w tym także z psychologii behawioralnej. Nie było to ani łatwe, ani w pełni możliwe, gdyż oprócz cenzury istniał system centralnej kontroli awansów naukowych, w wyniku którego negatywnie recenzowano rozprawy doktorskie i habilitacyjne, gdy ich autorzy

\footnotetext{
${ }^{38}$ Aldona Jawłowska, „Kontrkultura”, 7 i nast.
} 
odwoływali się do innego niż powyższy paradygmatu badawczego ${ }^{39}$. „Zachwianie dominującego w psychologii i socjologii akademickiej paradygmatu nastąpiło poprzez wprowadzenie wobieg kulturowy koncepcji psychologii humanistycznej, zorientowanej na samorealizację jednostki, i wspieranie jej duchowego rozwoju, a także poprzez próby zastąpienia tzw. obiektywnych sposobów badania ludzkiego świata przez wprowadzenie idei socjologii humanistycznej, refleksyjnej czy też krytycznej." ${ }^{\prime 0}$

Naukową debatę o oporze odnajdziemy w niezwykle interesującej analizie fenomenu społecznej przestrzeni buntu polskich kontestatorów w okresie „przed”, ,w trakcie” i „potransformacyjnym”, jakiej dokonał - na podstawie także badań biograficznych - wrocławski socjolog Paweł Rudnicki ${ }^{41}$. Autor przedstawił genezę buntu, wpływ otoczenia, refleksji własnych respondentów na temat oporu wobec rzeczywistości (w tym także w szkole) i związanych z nim emocji. Chciał w ten sposób zdobyć wiedzę „o człowieku, który dostrzega mechanizmy zniewolenia w swojej rzeczywistości i jest zdolny przeciwstawić się opresji”"2. Kategoria „opresja” staje się jedną z istotniejszych w tej rozprawie, a odwołuje się w niej do dwóch paradygmatów: krytycznego (podejście do tematu) i interpretatywnego (procedury badawcze). Porusza kwestie dotyczące wspieranego silnie przez władze zniewolenia ludzi, z którego wielu z nich nie zdawało sobie sprawy. Mamy w tym studium odsłonę polskiej specyfiki kontestacji lat 1970-1990, w której istotną rolę odegrały absolutnie fenomenalne jego zdaniem formy komunikacji społecznej jak muzyka rockowa, teatr, literatura, film. Sięgnął do teorii, które pozwalają na badanie zjawisk buntu w perspektywie uwarunkowań socjobiograficznych, a przyjmowanych przez badacza mniej lub bardziej świadomie.

Odwołując się do paradygmatów Szkoły Frankfurckiej, autor ten zastosował krytyczną analizę dyskursu celem zdemaskowania ograniczeń narzucanych jednostkom przez system i jego narzędzia, jakimi są socjalizacja polityczna oraz powszechnie obowiązująca edukacja. Badacz określa socjalizacjęjako rodzaj zniewolenia, pisząc między innymi: „Człowiek istniejący w systemie społecznym, politycznym czy ekonomicznym staje się nie tylko ich uczestnikiem, ale również i zakładnikiem, podlegając ciągłemu ubezwłasnowolnieniu, którego nie dostrzega." ${ }^{\star 3}$

\footnotetext{
39 Przykładowo, rozprawa habilitacyjna Stanisława Rucińskiego z fenomenologii pedagogicznego a radykalnego odrzucenia wychowania celowościowego, mogła ukazać się dzięki podtytułowi, choć z marksizmem niewiele miała wspólnego. Mimo pozytywnych recenzji wydawniczych nie została jednak przyjęta jako dysertacja habilitacyjna. Dopiero drugie wydanie (zmienione) tej rozprawy pod tytułem: Wychowanie jako wprowadzanie w życie wartościowe (Warszawa: Wydawnictwa Uniwersytetu Warszawskiego 1988), w mniejszej objętości i bez owego podtytułu zaowocowało pozytywnym przyjęciem przez środowisko naukowe dopiero w cztery lata później, bo w październiku 1992 roku, kiedy już nie obowiązywała cenzura i doktryna marksistowska w naszym kraju.

${ }^{40}$ Jawłowska, „Kontrkultura”, 20.

${ }^{41}$ Paweł Rudnicki, Oblicza buntu w biografiach kontestatorów (Wrocław: Wydawnictwo Dolnośląskiej Szkoły Wyższej 2009).

${ }^{42}$ Tamże, 11.

${ }^{43}$ Tamże, 17.
} 
Przyjęta przez P. Rudnickiego krytyczna perspektywa jest w dużej mierze zgodna z socjologią radykalną, która postuluje spojrzenie na całość społeczeństwa z perspektywy „dołów społecznych” ${ }^{4}$. Bada buntowników z tej właśnie perspektywy jako podlegających dominacji większości kulturowej. Badacz zmierza przez swoją działalność do zmiany społecznej, do naprawy społeczeństwa, dzięki temu, że dokonuje także wartościowania w kategoriach moralnych poznawanych zjawisk. Może osiągnąć ten cel, uświadamiając badanym fałszywe racjonalizacje ich własnych zachowań, ukazując im nieuzasadniony ucisk społeczny.

Dla pedagogów analiza prowadzonych sporów także w naukach politycznych może dawać asumpt do tego, by zobaczyć we własnej dyscyplinie „w jaki sposób intelektualiści i argumenty walczą o wpływ na politykę rządu i dlaczego jedna perspektywa może przejść od przewagi (hegemoniczna) do marginalizacji (opozycyjna), jeśli chodzi o wpływ na politykę rządu, zależnie od wydarzeń międzynarodowych i zmieniających się osobowości politycznych." ${ }^{45}$ Słusznie wskazuje się na to, że na arenie sporów o teorie widać wyraźnie, jak walczą one ze sobą o hegemonię w dwóch sferach: państwowej (możliwość wpływania na oświatę i procesy wychowania instytucjonalnego czy środowiskowego) oraz akademickiej (w której prowadzone są debaty oraz dyskusje zwolenników i przeciwników określonego podejścia teoretycznego do edukacji). Teorie zawsze będą potrzebne, by można było na ich podstawie interpretować i rozumieć rzeczywistość, odróżniać fakty oraz procesy istotne dla interesującego nas problemu od błahych, mniej ważnych. Dzięki różnym interpretacjom możliwe jest dociekanie ich istoty, a także ocena w kategoriach moralnych: co jest dobre, a co złe. To są kwestie między innymi legalności i lojalności działań, możliwej interwencji oraz koniecznej suwerenności, praw stanowionych i ich uniwersalności, a także innych.

Polska recepcja oraz ścieżka rozwoju pedagogiki krytycznej wynika z tego, że w naszym kręgu kulturowym, silnie nacechowanym indywidualizmem i wartościami chrześcijańskimi, znalazła ona bardzo przychylny odbiór, który jednak wraz z rozpoznawaniem różnych koncepcji oraz teorii w jej szerokiej strukturze zaczął częściowo stawać się zagrożeniem dla innych tradycji i nauk pedagogicznych nurtu związanego z nauką Kościoła czy humanistycznego o orientacji personalistycznej. Nie jestem pewien, czy opublikowana przez publicystę, teologa i filozofa Tomasza Bartosia analiza krytyczna życia oraz dzieła Jana Pawła $\mathrm{II}^{46}$ może być zaliczana do jednego z wielu nurtów współczesnej filozofii krytycznej w Polsce doby transformacji.

\footnotetext{
${ }^{44}$ Janusz Mucha, Socjologia jako krytyka spoleczna. Orientacja radykalna i krytyczna we wspótczesnej socjologii zachodniej (Warszawa: Wydawnictwo Naukowe PWN 1986).

${ }^{45}$ Scott Burchill, „Wstęp”, w: Scott Burchill i in., Teorie stosunków międzynarodowych, przeł. Paweł Frankowski (Warszawa: Książka i Wiedza 2006), 23.

${ }^{46}$ Filozof i teolog Tadeusz Bartoś napisał rozprawę w nurcie analizy krytycznej myśli Jana Pawła II: „[...] Tylko krytyczna recepcja może być twórcza. By zrozumieć autora, trzeba się z nim zmierzyć, poddać jego myśl ogniowej próbie analizy. [...] Podważanie, kwestionowanie to droga do lepszego zrozumienia, do poczynienia dystynkcji: przyjęcia i odrzucenia. „Dobrze rozróżnić” - to fundamentalna praca intelektualna”. Tadeusz Bartoś, Jan Pawet II. Analiza krytyczna (Warszawa: Wydawnictwo Sic! 2008), 11.
} 
Jak sam autor pisze: „Nowe czasy niosą nowe doświadczenia, dlatego potrzeba krytycznej refleksji, by papieskie dziedzictwo podjąć i w szlachetnym sporze «agonie» (jak o tym pisał Harold Bloom) - przekroczyć. Recepcja bowiem, przyjęcie i przetworzenie tradycji jest rzetelne jedynie w sporze, w zmaganiu nadającym myśli ramy, ustanawiającym horyzont. W przezwyciężeniu myśl rodzi się na nowo, w nowej postaci." ${ }^{47}$

Nie mam wątpliwości, że przed filozofią krytyczną broni się bardzo polska myśl psychologiczna, która podjęła w obszarze swoich studiów teoretycznych jedynie aspekt nauk krytyczno-hermeneutycznych jako podstawę do badań antynaturalistycznych. „Psychologia antynaturalistyczna (tu: hermeneutyczna) jest niejako «rozpięta» między tym, co ogólne (ogólne pojęcia, kategorie itp.), a indywidualnym ich «zastosowaniem». Oczywiście, «to, co ogólne», ma tu nieco inne rysy niż w przypadku nauk przyrodniczych. W tych ostatnich «ogólny» to przede wszystkim obowiązujący powszechnie (jak w sformułowaniu «prawo ogólne»4). Psychologia w perspektywie hermeneutycznej kładzie głównie nacisk na „,...] opis i rozumienie «związku sensu» (jako przedmiot i cel) oraz porozumienie - czy szeroko pojęty «dialog» (jako sposób docierania do tego celu)." ${ }^{" 49}$ Niestety nie ma u nas badań w nurcie psychologii nawiązującej do filozofii i socjologii krytycznej, jak ma to miejsce w świecie, gdyż dominuje w niej paradygmat badań naturalistycznych.

Tymczasem psychologia krytyczna ma swoje korzenie w amerykańskiej psychologii społecznej, gdzie podejmowane były badania i konstruowane teorie wyjaśniające społeczno-polityczne działania ludzi uwikłanych w makropolityczne konflikty, rywalizację i tym podobne. Jej rozwój zaznaczył swoją silną obecność wbadaniach zzakresu psychopatologii i psychoterapii, a nawet psychologii rozwojowej. Pierwszą monografią zbiorową z psychologii krytycznej była wydana w 1997 roku Critical Psychology: An Introduction pod redakcją Dennisa Foxa i Isaaca Prilleltensky'ego, w której przedstawiono różne jej nurty. Waleria Walkerdin utworzyła w 1998 roku Centrum krytycznej psychologii na University of Western Sydney, gdzie działało ono tylko do roku $2000^{50}$.

W Czechach od ponad dziesięciu lat prowadzony jest w naukach psychologicznych dyskurs na temat społecznego konstrukcjonizmu, postaw dekonstrukcyjnych i dekonstruowania tekstów psychologicznych (także zawartych w nich modeli, teorii czy konstruktów). Rozwój tej dyscypliny wiedzy jest nieustannie stygmatyzowany od lat $70 . \mathrm{XX}$ wieku przez przypisywanie mu miana antypsychologizującej herezji. Jak pisze Zbynĕk Vybíral, „Psychologia krytyczna stała się meta-wiedzą wobec podstaw subdyscyplin psychologii. W historii psychologii przygląda się jej historycznym, społecznym i ideologicznym kontekstom; na przykład

\footnotetext{
${ }^{47}$ Tamże, 147.

48 Joanna Trzópek, Filozofie psychologii. Naturalistyczne i antynaturalistyczne podstawy psychologii wspótczesnej (Kraków: Wydawnictwo UJ 2006), 153.

${ }^{49}$ Tamże, 154 .

${ }^{50}$ Zbynek Vybíral, Psychologie jinak. Současná kritická psychologie (Praha: Academia 2006).
} 
w psychologii osobowości psycholog krytyczny pyta, zjakiej pozycji jest charakteryzowana tak zwana zdrowa osobowość i na bazie jakich kryteriów rozstrzyga się o tym, co jest nienormalnością i patologią. Docieka, jak historyczny i ideologiczny kontekst rozwoju danej subdyscypliny naznaczył znane koncepcje, metodologiczne podejścia - i w związku z tym jak generalizowano i utrwalano wiedzę na ten temat." ${ }_{1}$

Psychologia krytyczna określana jest też mianem bardziej psychologii zmiany czy dążącej do zmiany, niż krytycznej. Jawi się jako metadyscyplina, czyli nauka o nauce (psychologia psychologii, metapsychologia). Po prawie 30 latach swojego rozwoju wygenerowała dwa nurty: polityczny i intelektualnie krytyczny.

$\mathrm{W}$ nurcie politycznym kładzie się akcent na zaangażowanie, aktywność przeciwstawiającą się status quo zamierzonej aktywności. Jest to najbardziej radykalne skrzydło psychologii krytycznej, którego przedstawiciele walczą o odideologizowanie tej nauki czy demaskowanie jej powiązań z ideologią polityczną. W ostatnich latach zwraca się uwagę na manipulacje medialne, które wykorzystują analfabetyzm czy półanalfabetyzm części społeczeństwa dla potrzeb marketingu i propagandy.

Natomiast intelektualnie krytyczny (teoretyczny, postmodernistyczny) nurt badań przeciwstawia się psychologii mainstreamowej. Przedmiotem badań psychologicznych są krytyczne analizy dyskursów. J. Gergen zwraca uwagę na to, że współczesna dyskusja w łonie samej psychologii nad uwarunkowaniami jej teorii jawi się jako antypsychologia. Jednym z jej prowokacyjnych pytań jest dociekanie tego, wjakim stopniu są jeszcze aktualne w psychologii społecznej wyniki badań eksperymentalnych, które prowadzone były kilkadziesiąt lat temu w warunkach symulowanych lub co robi psychologia z samymi psychologami, w jakim stopniu naznacza i fiksuje ich przekonania, postawy, wizje ${ }^{52}$.

W psychologii krytycznej wyróżnia się kilka prądów, których istotą jest praktyczne wyeliminowanie przemocy: tak z samej psychologii, jak i ze społeczeństwa. Nie jest obojętne to, w jakim stopniu psychologia jako nauka i sami psycholodzy są wykorzystywani ideologicznie w służbie władzy. Wymienia się tu następujące prądy:

1. Etnopsychologia jako krytyka fałszywych konstruktów zachodnich: podważa się uniwersalizm psychologii brytyjskiej i amerykańskiej, wskazując na niedostrzeganie hinduskiej psychologii, która wytworzyła własne kategorie pojęciowe - self, tożsamość i świadomość, spirytualne korzenie ontologii, holistyczne pojmowanie świata, nielinearny wzrost w ramach cyklu życia oraz inne.

2. Psychologia dyskursywna: zajmująca się zastosowaniem języka, aktami mowy, aktywnością dyskursywną, jej źródłem, strategią, repertuarem lingwistycznym, tekstem i jego wytwarzaniem, w tym także manipulacją. Rolą psychologów krytycznych zorientowanych na badanie dyskursów jest odkrywanie i opisanie tego,

\footnotetext{
${ }^{51}$ Tamże, 21 [tłumaczenie własne tu i w dalszych cytatach].

52 Tamże, 31.
} 
jak specjaliści obchodzą się z językiem, w jakim stopniu język służy społecznym, ideologicznym i politycznym interesom; wreszcie badanie treści tekstów w zakresie zbieżności tego, co psycholog opisuje czy twierdzi z jego wrażliwością, postawami czy miejscem w społeczeństwie ${ }^{53}$.

3. Metapsychologia (spojrzenie psychologii na samą siebie w obrębie każdej jej teorii).

4. Radykalna psychologia rozumiana jako prąd polityczny, który przyznaje się do związków z tradycyjnym neomarksizmem, lewicowym utopizmem i europejskim anarchizmem. Jej ambicją jest zmiana społeczeństwa w wyniku wspierania emancypacji jednostek i stawiania oporu wobec przemocy. „W psychologii radykalnej dominują dwie wizje: cel transformowania społeczeństwa na wzór wizjonerski «dobrego społeczeństwa» bez społecznych nierówności oraz transformowanie psychologii tak, by lepiej służyła zmianom w społeczeństwie. Psycholodzy mają wyjść z katedr uniwersyteckich i aktywnie, niemalże anarchistycznie włączyć się $\mathrm{w}$ walkę przeciwko mainstreamowej psychologii, która należy do jednej z implicite dyskryminujących instytucji naszych czasów." ${ }^{4} W$ tym nurcie rozwijają się też: antypsychiatria (upominająca się o poszanowanie godności pacjentów) oraz badania psychologiczne nad rasizmem, polityką, demonstracjami, migracją, ale i tożsamością, duchowością czy teoriami podmiotowości.

5. Feministyczna psychologia, której przedstawiciele odczytują w tekstach z psychologii klinicznej i rozwojowej dominację perspektywy androcentrycznej czy nawet fallocentrycznej, a więc pisanie z pozycji męskiego i heteroseksualnego eksperta wykazującego „normalność” kobiet, jeśli są one oddane swoim mężczyznom. Sue Wilkinson wyróżnia tu aż pięć podejść jako bardzo krytycznych wobec głównych prądów współczesnej psychologii. Są to: 1) krytyka „pomiaru” cech kobiecych z perspektywy norm ustanawianych przez mężczyzn; 2) zinternalizowana przemoc w wyniku socjalizacji prowadzącej do kompleksów niższości i zaniżania ambicji; 3) wsłuchiwanie się w „głos kobiecy”, by to nie mężczyźni, ale kobiety własnym głosem mówiły o swoich problemach; 4) wykluczenie pytania o różnice między mężczyznami a kobietami w wyniku przyjęcia $\mathrm{w}$ badaniu perspektywy integrującej cechy męskie i żeńskie wewnątrz jednej osoby (psychiczna androgynia); 5) feministyczny konstrukcjonizm społeczny jako radykalny kierunek w psychologii krytycznej, którego przedstawiciele twierdzą, że „seksistowska społeczność nie tylko konstruuje psychologiczne atrybuty męskości i kobiecości, ale także mężczyzn i kobiety, które są również źródłem seskistowskiej przemocy." 55

Najnowszą pracą z zakresu badań nad kierunkami współczesnej psychologii, której autorka docieka alternatywnych podejść wobec dominującego w tej dyscyplinie nauk paradygmatu pozytywistycznego, jest analiza teoretycznego zaplecza psychologii autorstwa Viery Bačovej. Słowacka komparatystka przyznaje na wstępie, że osobiście sympatyzuje z prezentowanymi prądami „współczesnej psychologii”, która jest dla

\footnotetext{
${ }^{53}$ Tamże, 39.

${ }^{54}$ Tamże, 45 .

${ }^{55}$ Alena Plháková, Dějiny psychologie (Praha: Grada Publishing 2008), 295 [thumaczenie własne].
} 
niej de facto psychologią krytyczną dehumanizacji psychologii, w psychologii i z udziałem psychologii. „Badania psychologiczne są schematyczne, powtarzalne, nudne a czasami wykonywane całkiem bezmyślnie. Nie przynoszą nic nowego, czego ludzie by nie rozumieli, a co pomogłoby im żyć, ale wprost przeciwnie, stosują rzekomo «naukową» metodologię i kryteria «obiektywności»." ${ }^{\text {"6 }}$ Tymczasem - jej zdaniem - każda psychologia jest przesiąknięta politycznymi interesami, co jest widoczne w podejmowanych przez nią problemach badawczych, w koncepcjach na temat dobrego (szczęśliwego) życia czy dobra społecznego. Odwołując się do myśli Michela Foucaulta, konstatuje, że psychologiczna retoryka oraz konstruowane teorie negatywnie wpływają na życie ludzi, którzy są z udziałem instytucji oraz praktyk terapeutycznych dyscyplinowani, kontrolowani, prowadzeni mimo obiecywanej im podmiotowości czy odzyskania utraconego poczucia wartości i autonomii.

Bačová prezentuje szeroką, a wciąż mało znaną w Polsce, paletę psychologii krytycznej, wyróżniając w niej kilka szkół badawczych:

1) Etogeniczną i dyskursywną psychologię angielskiego filozofa oraz profesora psychologii Roma Harrego, który wraz z psychologiem społecznym Paulem F. Secordem na początku lat 70. XX wieku rozwinął i wzbogacił koncepcje etnometodologii badań mikrosocjologicznych Harolda Garfinkela, Errvinga Goffmana i Georga Kelly'ego. Krytyka dotyczy tu manipulacji zmiennymi w ramach eksperymentów psychologicznych pomijających rolę prawidłowości społecznych oraz kulturowych życia człowieka. Teorie psychologiczne przecież są także tekstami napisanymi przez badaczy, zatem odzwierciedlają ich implicytną (ukrytą) osobowość i jaźń społeczną mimo wmawiania czytelnikom, że przedstawiają „obiektywne” zjawiska i prawidłowości ${ }^{57}$. Interesująca jest tu krytyka mocno zakorzenionej także w Polsce teorii Erika H. Eriksona, która - w świetle psychologii krytycznej - jest ograniczona tylko do klasy średniej i wyżej, a więc nieadekwatna do osób socjalizowanych w środowiskach marginalnych ekonomicznie, defaworyzowanych w związku z tym także społecznie (nie mają one do dyspozycji moratorium, czyli koniecznego okresu wolnego eksperymentowania z rolami i możliwości przeżywania kryzysów); przy tym ów model jest skonstruowany dla mężczyzn.

2 ) Społeczny konstrukcjonizm w psychologii, którego twórcami są w tej dyscyplinie John Shotter oraz Kenneth J. Gergen, odrzucający tezę, że badany przedmiot można opisać czy definiować „obiektywnie i neutralnie”, skoro jest on konstrukcją badacza, tworzoną i prezentowaną jako jedną z wielu wersji opisu świata ludzkiego. Nazwa „konstrukcjonizm” ma odróżniać tę szkołę badawczą od konstruktywizmu w socjologii. W psychologii cechuje ją: antyesencjalizm, antyindywidualizm, historyczna (temporalnie i lokalnie) specyficzność kultury poznania, język jako warunek myślenia i forma społecznej aktywności, akcent na interakcję, relacje i procesy społeczne oraz większy nacisk na struktury społeczne ${ }^{58}$.

\footnotetext{
${ }^{56}$ Viera Bačová, Súčasné smery v psychologii. Hladanie alternatív pozitivizmu (Bratislava: VEDA 2009), 10 [tłumaczenie własne tu i w dalszych cytatach].

${ }^{57}$ Tamże, 61.

${ }^{58}$ Tamże, 68.
} 
Społeczny konstrukcjonizm w psychologii ma za zadanie między innymi demistyfikować rzekomą neutralność poznania oraz ujawniać przesłanki polityczne i ideologiczne w nauce. Bačová wymienia pięć jego celów: „1) dekonstruowanie ideologicznej zawartości w powszechnie już uznanej wiedzy (na przykład ideologia homoseksualnej orientacji jako patologii osoby albo wiedza na temat «naturalnych» cech mężczyzn i kobiet); 2) dekonstruowanie mistyki, która otacza nauki społeczne i jest podtrzymywana przez ich przedstawicieli, by zachować przywileje; 3) rozpoznanie i uznanie refleksyjności w swojej teorii; 4) oferowanie radykalnie odmiennych definicji świata, który mami, szokuje, wzbudza gniew albo zaskakuje w tym, że krytykuje to, co jest uznawane za pewne; 5) otwarte i eksplicytne moralne i polityczne wartościowanie alternatywnych konstrukcji, jakie prezentuje badanie, a które określa jako neutralne aksjologicznie." ${ }^{99}$

3 ) Psycholingwistyka i kognitywistyczne badania j ę z y k a : powrót w psychologii do badań nad językiem, konwersacją i dyskursem, co zwraca uwagę na to, iż poznanie nie jest neutralne, amoralne, ale właśnie moralne. Istotne są w tym nurcie badania Roma Harre'a, Paula F. Secorda, Noama Chomsky'ego, Georga A. Millera, Johna Shottera, Johna Langshaw Austina, Jonathana Pottera czy Margaret Wetherell i innych. Dzięki temu nurtowi rozwinęla się w psychologii semiologia oraz powstała teoria aktów mowy. Kluczowe przesłanki tego podejścia badawczego są następujące: „a) interakcje i komunikacja między ludźmi zawierają przede wszystkim język - kompleksowy system symboli; b) wiele naszych działań urzeczywistniamy za pomocą języka - nasze rozmowy, pisanie nie żyją jedynie w obszarze pojęć, ale są też mediami naszej aktywności; c) podstawa kultury tkwi w języku, d) język jest nierozerwalnie powiązany z procesami myślenia i sądzenia. Nie można sobie wyobrazić bez języka przebiegu złożonej komunikacji czy myślenia abstrakcyjnego."60

4) A n a li z a d y s k u r s u , przez który rozumie się w psychologii bardzo szeroko „sposób, modus, reżim przekazu, opisu, wyjaśniania porządku rzeczy. To jest zarówno treść, jak i sposób wyrażania, komunikowania oraz jego zasady. Obejmuje on wszystkie formy przejawów językowych, a więc oznajmianie, uzgadnianie, rozmowę, komunikację konfliktową, retorykę, wszystkie formy formalnej i nieformalnej interakcji, pisanie tekstów wszelkiego rodzaju. To język ciała, sposób ubierania się i prezentowania, wszystkie możliwe przejawy, które pozwalają dzielić się sensem czegoś. Dyskursem są metafory, reprezentacje, opowiadania, twierdzenia, oświadczenia, preferowane tematy itd. które we wspólny dla siebie sposób produkują określoną wersję zjawisk." ${ }_{1}$

5) Krytyczna psychologi a jest tym kierunkiem, który jako heterodoksja (czy nawet herezja) przewartościowuje podstawowy program dotychczasowej psychologii, występując przeciwko tradycyjnej, (neo)pozytywistycznej,

\footnotetext{
${ }^{59}$ Tamże, 78.

${ }^{60}$ Tamże, 93.

${ }^{61}$ Tamże, 111.
} 
kwantytatywnej metodologii i eksperymentalizmowi. To ruch krytykujący ortodoksję psychologiczną, która „gwarantowała” obiektywność poznania, odkrywanie uniwersalnych praw zachowań ludzkich, neutralność, wychodzenie ze zredukowanego indywidualistycznego modelu, absencję wartości czy oddzielenie metodologii badań od teorii. Tu chodzi o radykalną zmianę w psychologii, a tym samym także w o zmianę społeczeństwa, by psychologia nie wspierała instytucji społecznych, które wytwarzają niezadowalające i niesprawiedliwe warunki życia człowieka. Nie można w badaniach inteligencji unikać kontekstu kulturowego osób badanych. Psychologia krytyczna zwraca uwagę na relacje między psychologią tradycyjną a władzą, która ją wykorzystuje instrumentalnie do podejmowania kluczowych w państwie decyzji w sferze mass mediów, służby zdrowia, placówek opiekuńczo-wychowawczych, szkolnictwa i innych. Sposoby postępowania rządzących wobec ludzi znajdują upełnomocnienie w diagnozach psychologicznych oraz dostosowanej do oczekiwań i interesów politycznych władzy interpretacjach danych, które mają służyć dyscyplinowaniu jednostek, kontrolowaniu ich, a nawet stygmatyzowaniu. Psychologia krytyczna podkreśla negatywne skutki „metodolatrii” (metodologizmu), które stało się „,zczeniem metod aż do punktu pełnej wiarygodności i fetyszyzowania”. Jak twierdzi Beryl C. Kurt, metody psychologii tradycyjnej, dominującej, są jak idole, którym przypisuje się metastabilność, nie podlegają krytyce, nie są podawane w wątpliwość. Inkwizytorzy metodologiczni wytworzyli podział w psychologii na tak zwaną grupę „twardych badaczy” i tych marginalnych, „miękkich” (psychoanaliza, psychologia humanistyczna czy fenomenologiczna) ${ }^{62}$.

6) Psychologia feministyczna i feministyczne badania w psychologi i nie mają prowadzić do wytworzenia jakiejś odrębnej metody badań feministycznych czy feministycznej metodologii w badaniach psychologicznych, ale powinny uwzględnić w swoich analizach teoretyczne i kwestie polityczne, które stawiają problem uwarunkowań płciowych (rodzaju) w poznaniu oraz ich wpływ na kryteria poznania. Badacz bierze większą odpowiedzialność za to, jak interpretuje różne sytuacje oraz wjakim stopniu kieruje się swoimi uwarunkowaniami płciowymi w czasie prowadzenia badań. Richard D. Ashmor wyróżnia następujące paradygmaty psychologii feministycznej: a) badanie różnic między płciami; b) płeć jako zmienna osobowa albo jako androgynia (idealna rola według płci), c) rodzaj jako kategoria społeczna ${ }^{63}$.

O ile polscy psycholodzy są wtym kontekście opóźnieni wbadaniach współczesnej myśli, także nurtu krytycznego, o tyle filozofowie, pedagodzy i socjolodzy zaliczani są tu do krajowej czołówki, chociaż tak badania empiryczne, jak i analiza dyskursów $\mathrm{w}$ większości ośrodków prowadzona jest równolegle, bez wzajemnego sięgania po wyniki. Można też dostrzec, że mimo, iż większość rozpraw psychologa krytycznego Ericha Fromma została przełożona na język polski, pedagodzy nie korzystają z nich do własnych analiz. Tymczasem sięgają po nie nieustannie

\footnotetext{
62 Tamże, 143 .

63 Tamże.
} 
psycholodzy i psychoterapeuci, filozofowie, socjolodzy, a nawet politolodzy. W Niemczech ukazała się przed laty interesująca praca zbiorowa pod redakcją Johannesa Classena, w której autorzy zastanawiali się nad zakresem oddziaływania myśli tego wybitnego psychologa wnaukach o wychowaniu i obszarach możliwych jej zastosowań w praktyce edukacyjnej ${ }^{64}$.

Fromm dokonał bardzo interesującej diagnozy społeczeństwa kapitalistycznego (z perspektywy psychologii krytycznej): nie tylko określił istotę wychowania, kształcenia oraz uczenia się, ale też wskazał na zagrożenia, jakie prowadzą do ich destrukcji. W jego ujęciu wychowanie jest pomocą dziecku w tym, by mogło ono realizować swój potencjał rozwojowy, czego przeciwieństwem jest manipulacja. Fromm postawil w związku z tym pytanie, w jakim stopniu uwarunkowania ekonomiczne oraz społeczne warunki codziennego życia rzutują na te procesy. Sam opowiedział się jednoznacznie za tym, by wychowanie człowieka było wychowywaniem go ku byciu człowiekiem. W tym sensie jego zainteresowania badawcze wiążą się z etycznymi aspektami życia osoby w społeczeństwie, z rozumieniem wolności i korzystaniem z niej w sposób, który nie naruszałby istoty wartości ludzkiego życia. Wolność jest dla Fromma potencjałem odwagi, dzielności do podejmowania decyzji, by nasze życie było rzeczywiście możliwością realizowania dobra, prawdy, twórczości i miało sens.

W naukach o wychowaniu nie znalazła też jeszcze swojej recepcji rozprawa filozofa Andrzeja Szahaja, którą tenże poświęcił frankfurckiej szkole krytycznej. Jego studium nie jest - jak sam o tym pisze - „żadną komplementarną monografią, ani też gruntownym studium krytyczno-analitycznym. Nie wyczerpuje w żaden sposób tematu. Koncentruje się na przedstawieniu i skomentowaniu jedynie wybranych idei szkoły frankfurckiej oraz twórczości tylko kilku jej przedstawicieli [...]" ${ }^{\prime 6}$. Autor nie zamierzał też w swojej rozprawie przedstawić instytucjonalnych dziejów szkoły frankfurckiej, gdyż interesowała go głównie „[...] możliwie syntetyczna rekonstrukcja głównych idei społeczno-politycznych oraz epistemologiczno-metodologicznych tzw. krytycznej teorii społeczeństwa, teorii powstałej właśnie w kręgu owej szkoły, często jednak zbyt pochopnie z nią utożsamianej." ${ }^{66}$

Zdaniem Szahaja rekonstrukcja jest zarazem interpretacją, hipotetyczną wykładnią określonej teorii, która ma swoje dwie zasadnicze wersje: wcześniejszą (klasyczną), odwołującą się do tekstów pierwszych twórców, prekursorów oraz późniejszą, zawartą w pracach opublikowanych przez jej kontynuatorów. Teoria krytyczna rezerwuje dla siebie status metateorii, metanauki, gdyż stosując „metodę dialektyczną, dąży do tego, aby uchwycić pierwotnie założoną całość społeczną, zapośredniczoną w swych momentach, nie posługując się przy tym jakimś aktem intuicji czy wglądu, lecz uporczywą rekonstrukcją tego, co ukryte - z tego, co jawne.”67

\footnotetext{
${ }^{64}$ Johannes Claßen, Erich Fromm und die Kritische Pädagogik (Weinheim und Basel: Beltz Verlag 1991).

${ }^{65}$ Andrzej Szahaj, Teoria krytyczna szkoły frankfurckiej. Wprowadzenie (Warszawa: WAiP 2008), 15.

${ }^{66}$ Tamże, 19.

${ }^{67}$ Tamże, 35 .
} 
Specyfika badań krytycznych sprowadza się zatem do następujących przesłanek:

- badacz odrzuca pozytywistyczną a złudną wiarę w „nagie fakty”, gdyż te są zmienne, pełne sprzeczności, uzyskują swe znaczenie dopiero w kontekście teorii, która je projektuje i interpretuje. „Nie ma ostatecznego obrazu rzeczywistości ani co do istoty, ani co do zjawiska [...]. Krytyczna teoria społeczeństwa powinna projektować programy badawcze, wktórych nauki szczegółowe współpracujące z filozofią, strzegącą posłannictwa teorii i organizującą ramę konceptualną i światopoglądową, powinny dostarczać materiału empirycznego nabierającego jednak sensu dopiero po ponownej teoretycznej interpretacji." ${ }^{\prime 68}$;

- badacz nie ukrywa swoich poglądów, wartości, nie sytuuje się na zewnątrz badanej rzeczywistości społecznej, nie udaje, że kieruje się emancypacyjnym interesem, gdyż jego dociekania są związane z horyzontem i interesami określonych grup; on sam zresztą wnosi w proces poznawczy cały bagaż dookreślenia biologicznego i kulturowego;

- badacz ma świadomość uwikłania nauki w praktykę społeczną, nie zadowala się postawą kontemplacyjną, gdyż jest zainteresowany zmianą;

- badacz podejmuje krytykę zaistniałego stanu rzeczy i walkę z nim w kierunku określonym przez samą teorię, przy czym krytyka ta może być i pozytywna, i negatywna. „Nicią przewodnią tej krytyki jest z jednej strony aktualna sytuacja bytowa człowieka jako rozumnej istoty żywej, tj. istoty żywej, której zadaniem jest wolne, kierowane przez wiedzę poznawczą samoksztaltowanie własnego bytu z uwagi na jej ziemskie «szczęście». Z drugiej strony nicią ta jest aktualny stan sił wytwórczych i zgodne z nim lub niezgodne stosunki produkcji jako miara dających się $\mathrm{w}$ danej chwili realizować możliwości rozumnego samokształtowania społeczeństwa." ${ }^{\circ}$;

- badacz demaskuje fałsz i paradoksy rzeczywistości badanej, ujawniając jej problematyczność, zmienność oraz tkwiące w niej czynniki alienacji społecznej, ograniczeń życiowych możliwości jednostek ludzkich;

- badacz dostosowuje teorię do zmieniającego się przedmiotu swoich badań, jakim jest rzeczywistość społeczna, ale podkreślając swoje silne związki z praktyką, dba o niezależność teoretycznego myślenia od bieżących interesów czy oczekiwań politycznych;

- badacz ma świadomość tego, że fakty społeczne są nieprzewidywalne, gdyż wpisują się w nie również irracjonalizmy, brak dystansu do badanej rzeczywistości, bowiem żadna nauka nie jest wolna od wartościowania.

Skoro teoria krytyczna ma służyć jakiejś grupie, „która jest aktualnie zainteresowana w zniesieniu istniejącego stanu niesprawiedliwości, zniewolenia i wyobcowania [...], to znaczy, że jej [...] głównym adresatem jest zawsze nieszczęśliwa

\footnotetext{
${ }^{68}$ Tamże, 35 .

${ }^{69}$ Tamże, 24.
} 
i ograniczona w swych życiowych możliwościach jednostka." ${ }^{70}$ Teoria krytyczna zachowa swoją aktualność tak długo, jak długo będzie istniała w społeczeństwie niesprawiedliwość społeczna. „Represywna tolerancja” systemu polega na tym, że dopuszcza się swobodę głoszenia wszelkich poglądów i pozwala na to, by się nawzajem znosiły i neutralizowały. Myśl alternatywna „pojawia się w nim stosunkowo rzadko, na zasadzie wyjątku od reguły, która nakazuje mniej czy bardziej świadomie aprobować wszystko to, co jest, gdy zaś się już pojawi, jest błyskawicznie absorbowana przez «system» stając się jeszcze jedną ofertą ideową." ${ }^{71}$ Tym samym system jest immunizowany na jakąkolwiek skuteczną krytykę i nie ma szans na zaistnienie w nim prawdziwej zmiany. „Teoria, którą uważamy za słuszną, może kiedyś zniknąć, gdyż znikną praktyczne i naukowe interesy odgrywające rolę przy tworzeniu pojęć, a przede wszystkim, gdyż wpierw znikną rzeczy i sytuacje, których one dotyczą." 72

System kapitalistyczny nie jest totalitarny, jeśli funkcjonują w nim mechanizmy zezwalające na wyrażanie przez ludzi sprzeciwu, a jest to możliwe w warunkach demokracji liberalnej. Skoro istnieje wiele odmiennych systemów wartości, z których każdy wyrasta z odmiennej kultury i wyraża jakiś ideał dobra, to pluralizm wartości obiektywnie funkcjonujący uruchamia politykę agonistycznie ścierających się ze sobą odmiennych teorii oraz filozofii życia. Nie można ich zatem uporządkować wedle jednej skali. Uznając istniejące między nimi różnice, wzbogacamy nasz sposób widzenia określonych zjawisk czy rzeczy. Nie ma możliwości usunięcia milczących założeń o charakterze kulturowym co do znaczenia używanych wyrażeń, które przesądzają o sposobie widzenia zjawisk interesujących badaczy. Jak pisze Szahaj: „nie ma stanowisk filozoficznych czy politycznych neutralnych aksjologicznie, niewspierających się na jakimś pierwotnym wyborze lub milcząco przyjętych przesłankach." ${ }^{.73}$ Poszukiwanie porozumienia między nimi jest bezzasadne, gdyż istniejące między nimi różnice kulturowe i polityczne są często bardzo głębokie. Można co najwyżej poznać argumenty, jakie konstytuują daną teorię, gdyż nie istnieje wspólne tło dla podzielanych przekonań na określony temat.

Badania teorii odwołujących się do założeń Szkoły Frankfurckiej i jej współczesnych kontynuatorów w różnych dyscyplinach naukowych powinny skupiać się na stawianiu pytań o aprioryczność ich własnych założen, uprzedzenia i nastawienia, jakie kryją się w umysłach zwolenników czy kreatorów tych teorii. Przecież nawet w obrębie tej samej szkoły teoretycznej badacze nie podzielają tych samych poglądów. „W rzeczywistości wiele najbardziej interesujących debat w obrębie nauki [...] toczy się właśnie między intelektualistami z tego samego nurtu. Różnorodność może być siłą. Czystość teorii niesie niewiele korzyści." 74 Zróżnicowanie teorii ma miejsce nie tylko w samej dyscyplinie naukowej, jaką jest

\footnotetext{
${ }^{70}$ Tamże, 23.

${ }^{71}$ Tamże, 53 .

72 Tamże, 31.

${ }^{73}$ Tamże, 220.

${ }^{74}$ Burchill, Wstęp, 30.
} 
pedagogika krytyczna, ale także wewnątrz subdyscyplin nauk o wychowaniu, które mogą być odczytywane w tej perspektywie.

Nierównomierny rozwój nauk pedagogicznych wynika właśnie z tego stopnia zróżnicowania teoretycznego w poszczególnych subdyscyplinach zjednoczesnym zawłaszczaniem dla siebie określonych problemów badawczych lub ich marginalizowaniem. Proces ten jest wprawdzie w ostatnich latach coraz silniej naruszany w wyniku sił globalizacji i fragmentacji wiedzy, umacniając podejrzliwość czy problematyczność istniejących już teorii. Każda próba rekonstruowania istniejących w danej nauce teorii oraz jej typologia jest do pewnego stopnia arbitralna i nie wynika z ich porównywania ze sobą w perspektywie interdyscyplinarnej. Dobrze, że dzięki monotematycznym debatom naukowym (jak ta we Wrocławiu poświęcona pedagogice krytycznej), możliwe jest sformułowanie tego, czego oczekujemy od siebie, a czego od innych, czego od praktyków, a czego od teoretyków - unifikacji czy zróżnicowania, pewności czy nieprzejrzystości, jednoznaczności czy nieoznaczoności.

Wybory do Sejmu w 2015 roku zawierały w sobie bunt młodego pokolenia. Czy polska pedagogika krytyczna weźmie udział w rewitalizacji własnego społeczeństwa? Zapytam zatem za Lechem Witkowskim: Czy pedagogika krytyczna przyczyni się do stworzenia nowej rzeczywistości edukacyjnej, eliminując z dotychczasowej „[...] wątki apologetyki państwa i promującą zdolność do samoregulacji społecznej, niezakłóconej władczymi ingerencjami i pośrednictwem aparatu etatyzacji oraz uchylającej mechanizmy degeneracji funkcji oświaty?"75 Odpowiedź na to pytanie została skierowana do całego środowiska.

Streszczenie: Artykuł stanowi wynik badań recepcji pedagogiki i psychologii krytycznej w naukach humanistycznych oraz społecznych w Polsce od końca lat 8o. XX do połowy drugiej dekady XXI wieku. W różnych uniwersytetach $\mathrm{w}$ kraju prowadzone są badania metateoretyczne i oświatowe podstawowych kategorii pedagogicznych oraz procesów edukacyjnych w szkolnictwie, których przesłanki tkwią w filozofii Szkoły Frankfurckiej, francuskiej, włoskiej i anglo-amerykańskiej krytycznej socjologii edukacji. Wykazuję, w jakim stopniu przekłady na język polski klasycznych rozpraw z filozofii, pedagogiki i psychologii krytycznej oraz hermeneutyczne badania nieobecnych w Polsce przekładów dzieł czołowych przedstawicieli tego nurtu myśli i praktyk wychowawczych w naukach o wychowaniu przyczyniły się z jednej strony do wzmocnienia transformacji ustrojowej w 1989 roku i zmian społecznych, z drugiej zaś, w jakim zakresie wpisują się w zupełnie nowe odczytanie pojęć, języka i teorii krytycznych z polskiej perspektywy przy zastosowaniu metodologii badań porównawczych.

Słowa kluczowe: filozofia krytyczna, pedagogika krytyczna, socjologia krytyczna, psychologia krytyczna, antypedagogika, opór, emancypacja, demokracja, klinika kształcenia, socjopatologie edukacji

\footnotetext{
${ }^{75}$ Witkowski, 38.
} 


\section{Bibliografia}

Bačová, Viera. Súčasné smery v psychologii. Hl’adanie alternatív pozitivizmu. Bratislava: VEDA, 2009.

Bartoś, Tadeusz. Jan Pawet II. Analiza krytyczna. Warszawa: Wydawnictwo Sic! S.c., 2008.

Bertrand, Yves. Soudobé teorie vzdělávání. přel. Oldřich Selucký. Praha: Portál, s. r. o., 1998.

Bilińska-Suchanek, Ewa. Opór wobec szkoły. Dorastanie w perspektywie paradygmatu oporu. Studium socjopedagogiczne. Słupsk: Pomorska Akademia Pedagogiczna w Słupsku, 2000.

Bilińska-Suchanek, Ewa. Nauczyciel i opór (wobec) systemu edukacji. Toruń: Wyd. Adam Marszałek, 2013. Brzezińska, Renata, Artur Brzeziński. Idee angielskiej wolnej szkoty Summerhill wpolskich egzemplifikacjach. Włocławek: Wydawnictwo Wyższej Szkoły Humanistyczno-Ekonomicznej we Włocławku, 2012.

Burchill, Scott. „Wstęp”. W: Scott Burchill i in. Teorie stosunków międzynarodowych, przeł. Paweł Frankowski. Warszawa: Książka i Wiedza, Warszawa, 2006.

Czerepaniak-Walczak, Maria. Pedagogika emancypacyjna. Rozwój świadomości krytycznej człowieka. Gdańsk: GWP, 2006.

Claßen, Johannes. Erich Fromm und die Kritische Pädagogik. Weinheim und Basel: Beltz Verlag, 1991.

Dudzikowa, Maria. Mit o szkole jako miejscu wszechstronnego rozwoju ucznia. Eseje etnopedagogiczne. Kraków: Oficyna Wydawnicza „Impuls”, 2001.

Dumowska, Bogumiła. Edukacja autorska w szkołach publicznych w Polsce. Kraków: Oficyna Wydawnicza „Impuls”, 2003.

Dybel, Pawel. Granice rozumienia i interpretacji. O hermeneutyce Hansa-Georga Gadamera. Kraków: Towarzystwo Autorów i Wydawców Prac Naukowych Universitas, 2004.

Dworakowska, Zofia, Aldona Jawłowska. „Wstęp”. W: Wolność w systemie zniewolenia. Rozmowy o polskiej kontrkulturze, red. Aldona Jawłowska, Zofia Dworakowska. Warszawa: Uniwersytet Warszawski. Instytut Stosowanych Nauk Społecznych, 2008.

Edukacja alternatywna XXI wieku, red. Bogusław Śliwerski, Zbyszko Melosik. Kraków: Oficyna Wydawnicza „Impuls”, 2010.

Edukacja w wolności, red. Bogusław Śliwerski. Kraków: Oficyna Wydawnicza „Impuls”, 1992.

Figiel, Monika. Szkoły autorskie w Polsce. Realizacje edukacyjnych utopii. Kraków: Oficyna Wydawnicza „Impuls”, 2001.

Giroux, Henry A., Lech Witkowski. Edukacja i sfera publiczna. Idee i doświadczenia pedagogiki radykalnej. Kraków: Oficyna Wydawnicza „Impuls” 2010.

Górniewicz, Józef. „Warunki i znaczenie kontestacji edukacyjnych XX wieku. Uwagi nie-kontestatora”. W: Kontestacje Pedagogiczne, Materiały III Sekcji Zjazdu Pedagogów, red. i wstęp Bogusław Śliwerski. Warszawa: ZG PTP, Oficyna Wydawnicza „Impuls“, 1993.

Jawłowska, Aldona. Drogi kontrkultury. Warszawa: PIW, 1975.

Jawłowska, Aldona. „Kontrkultura w poszukiwaniu nowych koncepcji człowieka i ludzkiego świata”. W: Wolność $w$ systemie zniewolenia. Rozmowy o polskiej kontrkulturze, red. Aldona Jawłowska, Zofia Dworakowska. Warszawa: Uniwersytet Warszawski. Instytut Stosowanych Nauk Społecznych 2008.

Konstruowanie autorskich programów ksztatcenia stymulujących i wspierających rozwój uczniów we wspótczesnej szkole, red. Janusz Gnitecki. Poznań: Biuletyn PTP oddział w Poznaniu, 2004.

Kontestacje Pedagogiczne, Materiały III Sekcji Zjazdu Pedagogów, red. i wstęp Bogusław Śliwerski. Warszawa: ZG PTP, Oficyna Wydawnicza „Impuls“, 1993. 
Kwieciński, Zbigniew. Socjopatologia edukacji. Warszawa: IRWiR PAN, 1992.

Kwieciński, Zbigniew. Tropy - ślady - próby. Studia i szkice z pedagogiki pogranicza. Poznań-Toruń: Wydawnictwo Edytor, 2000.

Kwieciński, Zbigniew. Między patosem a dekadencją. Studia iszkice socjopedagogiczne. Wrocław: Wydawnictwo Naukowe DSWE TWP, 2007.

Kwieciński, Zbigniew. Dylematy. Inicjatywy. Przebudzenia. Nad przestankami odrodzenia edukacji $w$ Polsce. Wrocław: Wydawnictwo Naukowe DSW, 2011.

Kwieciński, Zbigniew. Cztery i pót. Preliminaria. Liminaria. Varia. Wrocław: Wyd. Naukowe DSW, 2011.

Łukaszewicz, Ryszard. Edukacja z wyobraźnią czyli jak podróżować bez map. Wrocław: Wyd. Uniwersytetu Wrocławskiego, 1994.

Łukaszewicz, Ryszard. „Leczenie głupoty” i... czyli Salony Edukacji Ekologicznej NATURAmy. Wrocław: Wyd. Uniwersytetu Wrocławskiego, 1996.

Łukaszewicz, Ryszard. Szkoła jako kawałek innego świata. Wrocław: Fundacja Wolne Inicjatywy Edukacyjne, 1997.

Łukaszewicz, Ryszard. Studia nad alternatywami wedukacji. Wrocław: Fundacja Wolne Inicjatywy Edukacyjne, 2002.

Łukaszewicz, Ryszard. Wroctawska Szkoła Przyszłości. Dla duchowości, dla wyobraźni, dla praktyki... z nieoczekiwana przypowieściq̨ autobiograficzna. Wrocław: Fundacja Wolne Inicjatywy Edukacyjne, 2011.

Melosik, Zbyszko, Tomasz Szkudlarek. Kultura, tożsamość i edukacja. Migotanie znaczeń. Kraków: Oficyna Wydawnicza „Impuls”, 1998.

Mollenhauer, K. Erziehung und Emanzipation - Polemische Skizzen. München: Juventa Verlag, 1973.

Mucha, J. Socjologia jako krytyka spoleczna. Orientacja radykalna i krytyczna we wspótczesnej socjologï zachodniej. Warszawa: PWN, 1986.

Nalaskowski,Aleksander. Szkołajako opus dei Liceum Ogólnokształcace PW „Poltech”. Toruń: PW „Poltech”, 1991.

Nalaskowski, Aleksander. Edukacja, która nie chce przeminaćc. Kraków: Oficyna Wydawnicza „Impuls”, 1999.

Nalaskowski, Aleksander. Widnokręgi edukacji. Kraków: Oficyna Wydawnicza „Impuls”, 2002.

Pasikowski, Sławomir. Ambiwalencja i opór. Nauczyciele i studenci wobec szkoły. Słupsk: Wyd. Akademii Pomorskiej w Słupsku, 2014.

Plháková, Alena. Dějiny psychologie. Praha: Grada Publishing, 2008.

Przyborowska, Beata. Struktury innowacyjne w edukacji. Teoria. Praktyka. Rozwój. Torun: Wyd. Naukowe UMK, 2003.

Retter, Hein. Grundrichtungen pädagogischen Denkens. Eine erziehungswsissenschaftliche Einführung. Bad Heilbrunn: Verlag Julius Klinkhardt, 1997.

Ruciński, Stanisław. Wychowanie jako wprowadzanie wżycie wartościowe. Próba marksistowskiego określenia aksjologicznej imetodologicznej problematyki ideahu wychowawczego. Warszawa: Wydawnictwa Uniwersytetu Warszawskiego, 1981.

Różnica, tożsamość, edukacja. Szkice z pogranicza, red. Tomasz Szkudlarek. Kraków: Oficyna Wydawnicza „Impuls”, 1995.

Rudnicki, Paweł. Oblicza buntuw biografiach kontestatorów. Wrocław: Wyd. Dolnośląskiej Szkoły Wyższej, 2009. Staniszkis, Jadwiga. Postkomunizm. Próba opisu. Gdańsk: słowo/obraz terytoria, 2001.

Starczewska, Krystyna. „Światopoglądy. Rozmowa 02. Rozmawiali Aldona Jawłowska i Aleksander Wasiliew”. W: Wolność w systemie zniewolenia. Rozmowy o polskiej kontrkulturze, red. Aldona 
Jawłowska, Zofia Dworakowska. Warszawa: Uniwersytet Warszawski, Instytut Stosowanych Nauk Społecznych, 2008.

Szahaj, Andrzej. Teoria krytyczna szkoły frankfurckiej. Wprowadzenie. Warszawa: WAiP, 2008.

Szkudlarek, Tomasz, Bogusław Śliwerski. Wyzwania pedagogiki krytycznej i antypedagogiki. Kraków: Oficyna Wydawnicza „Impuls”, 1991.

Szkudlarek, Tomasz. „McLaren i Agata: o pewnej możliwości interpretacji rytualnego oporu przeciw szkole”.

W: Nieobecne dyskursy, red. Zbigniew Kwieciński, cz. 2. Toruń: Studia Kulturowe i Edukacyjne, 1992.

Szkudlarek, Tomasz. Wiedza i wolność w pedagogice amerykańskiego postmodernizmu. Kraków: Oficyna Wydawnicza „Impuls”, 1993.

Szkudlarek, Tomasz. „Pedagogika krytyczna”. W: Pedagogika. Podręcznik akademicki, red. Zbigniew

Kwieciński, Bogusław Śliwerski, tom I. Warszawa: WN PWN, 2003.

Śliwerski, Bogusław. „Czy musimy wychowywać?”. Harcerz Rzeczypospolitej 5 (1988).

Śliwerski, Bogusław. „Antypedagogika”. Kwartalnik Pedagogiczny 1 (1990).

Śliwerski, Bogusław. Przekraczanie granic wychowania. Od "pedagogiki dziecka" do antypedagogiki. Łódź: Wydawnictwo Uniwersytetu Łódzkiego, 1992.

Śliwerski, Bogusław. „Pedagogika krytyczna”. Szkoła Zawodowa 10 (1992).

Śliwerski, Bogusław. Wyspy oporu edukacyjnego. Kraków: Oficyna Wydawnicza „Impuls”, 1993 (II wyd. 2009).

Śliwerski, Bogusław. Edukacja autorska. Kraków: Oficyna Wydawnicza „Impuls”, 1996 (II wyd. 2009).

Śliwerski, Bogusław. Edukacja pod prąd. Kraków: Oficyna Wydawnicza „Impuls”, 2001 (II wyd. 2009).

Śliwerski, Bogusław. Współczesne teorie i nurty wychowania. Kraków: Oficyna Wydawnicza „Impuls”, 1998.

Śliwerski, Bogusław. Jak zmieniać szkołę?. Kraków: Oficyna Wydawnicza „Impuls”, 1998 (II wyd. 2009).

Śliwerski, Bogusław. „Pedagogika negatywna”. W: Pedagogika. Podręcznik akademicki, red. Zbigniew

Kwieciński, Bogusław Śliwerski, tom I. Warszawa: WN PWN, 2003.

Śliwerski, Bogusław. Pedagogika dziecka. Studium pajdocentryzmu. Gdańsk: GWP, 2007.

Śliwerski, Bogusław. Wspótczesna myśl pedagogiczna. Znaczenia. Klasyfikacje. Badania. Kraków: Oficyna Wydawnicza „Impuls”, 2009.

Śliwerski, Bogusław. Problemy współczesnej edukacji. Dekonstrukcja polityki oświatowej III RP. Warszawa: WAiP, 2009.

Śliwerski, Bogusław. „Kontestacja pedagogiki końca XX wieku”. W: Nieobecne dyskursy, cz. 1, red. Zbigniew Kwieciński, Studia Kulturowe i Edukacyjne. Toruń: Wydawnictwo UMK, 1991.

Trzópek, Joanna. Filozofie psychologii. Naturalistyczne iantynaturalistyczne podstawy psychologii wspótczesnej. Kraków: Wyd. Uniwersytetu Jagiellońskiego, 2006.

Urbaniak-Zając, Danuta. Pedagogika spoleczna w Niemczech. Stanowiska teoretyczne i problemy praktyki. Łódź: Wyd. Uniwersytetu Łódzkiego, 2003.

Vybíral, Zbynek. Psychologie jinak. Současná kritická psychologie. Praha: Academia, 2006.

Witkowski, Lech. „Śmiech jako opór i wyzwolenie (pogranicze wiedzy, wiary i władzy)”. , w: Nieobecne dyskursy, red. Zbigniew Kwieciński, cz. 1. Toruń: Studia Kulturowe i Edukacyjne, 1991.

Witkowski, Lech. „Wokół teorii i praktyki rytuałów szkolnych”, w: Nieobecne dyskursy, red. Zbigniew Kwieciński, cz. 2. Toruń: Wydawnictwo Uniwersytet Mikołaja Kopernika, 1992.

Witkowski, Lech. „W kręgu pedagogiki radykalnej (dekonstrukcja, walka, etyczność)”, w: Spory o edukację. Dylematy i kontrowersje we wspótczesnych pedagogiach, red. Zbigniew Kwieciński, Lech Witkowski. Warszawa: IBE, 1993. 
Wrocławska Szkoła Przyszłości. Przestanki eksperymentu nad szkoła, red. Ryszard Łukaszewicz. Wrocław: Acta Universitatis Wratislaviensis No 396, Prace Pedagogiczne XIII, 1978.

Wrocławska Szkoła Przyszłości. Autonomia dziecka w procesie edukacji, red. Ryszard Łukaszewicz. Wrocław: Acta Universitatis Wratislaviensis No 851, Prace Pedagogiczne LVII, 1987.

Wychowanie. Pojęcia. Procesy. Konteksty. Interdyscyplinarne ujęcie, red. Maria Dudzikowa, Maria Czerepaniak-Walczak, tom 4. Gdańsk: GWP, 2008. 